Int. J. Dev. Biol. 52: 571-584 (2008)

doi: $10.1387 /$ ijdb.0725601s

\title{
The role of the actin cytoskeleton in calcium signaling in starfish oocytes
}

\author{
LUIGIA SANTELLA*, AGOSTINA PUPPO and JONG TAI CHUN \\ Cell Signaling Laboratory, Stazione Zoologica Anton Dohrn, Napoli, Italy
}

\begin{abstract}
Ca}^{2+}$ is the most universal second messenger in cells from the very first moment of fertilization. In all animal species, fertilized eggs exhibit massive mobilization of intracellular $\mathrm{Ca}^{2+}$ to orchestrate the initial events of development. Echinoderm eggs have been an excellent model system for studying fertilization and the cell cycle due to their large size and abundance. In preparation for fertilization, the cell cycle-arrested oocytes must undergo meiotic maturation. Studies of starfish oocytes have shown that $\mathrm{Ca}^{2+}$ signaling is intimately involved in this process. Our knowledge of the molecular mechanism of meiotic maturation and fertilization has expanded greatly in the past two decades due to the discovery of cell cycle-related kinases and $\mathrm{Ca}^{2+}$ mobilizing second messengers. However, the molecular details of their actions await elucidation of other cellular elements that assist in the creation and transduction of $\mathrm{Ca}^{2+}$ signals. In this regard, the actin cytoskeleton, the receptors for second messengers and the $\mathrm{Ca}^{2+}$-binding proteins also require more attention. This article reviews the physiological significance and the mechanism of intracellular $\mathrm{Ca}^{2+}$ mobilization in starfish oocytes during maturation and fertilization.
\end{abstract}

KEY WORDS: cell activation, sperm-egg interaction, meiosis, germinal vesicle, cyclic ADP ribose, NAADP

\section{Starfish oocytes and maturation-promoting factor}

Starfish oocytes have contributed greatly to our understanding of the molecular mechanisms controlling the cell cycle (maturation) and fertilization. During oogenesis, the oocytes undergo cell growth and differentiation bringing them to the end of the first prophase of meiosis where they remain synchronously arrested until spawning (Fig. 1). At this stage of maturation, the oocytes are characterized by a very large nucleus (approximately $60 \mu \mathrm{m}$ in diameter) termed the germinal vesicle (GV) (Fig. 2). The starfish oocyte has several advantages as an experimental model system. First, the cell is large and nearly transparent, making it suitable for imaging experiments after microinjection of fluorescent markers. Second, maturation (or meiosis re-initiation) can be induced in vivo and in vitro by the hormone 1-methyladenine (1$\mathrm{MA}$ ), rendering the oocytes successfully fertilizable (Kanatani et al., 1969; Meijer and Guerrier, 1984). The first visible sign of oocyte maturation is the germinal vesicle breakdown (GVBD) in which the large nucleus breaks down to release its nucleoplasm into the cytoplasm 20-30 minutes after the application of the hormone. This is how the starfish oocyte is conspicuously different from sea urchin eggs, which are already mature at the time of spawning. In sea urchins, the haploid egg pronucleus has a complete nuclear envelope, and the chromatin is decondensed in the interphase of the first mitosis.

One of the most dramatic events that follows hormonal stimulation of starfish oocytes is protein phosphorylation, which is associated with the increase of protein kinase activity (Guerrier et al., 1977). Indeed, the idea that the cyclin-dependent kinase Cdc2/CDK1-cyclin B plays a pivotal role in the control of the G2/ $\mathrm{M}$ transition phase of the cell cycle also came from the physiological studies of the starfish oocytes (Dorée and Hunt, 2002). Following the discovery that the progesterone-matured frog oocytes produce a cytoplasmic factor that causes maturation (hence, named "Maturation-Promoting Factor" or MPF) (Masui, 2001), similar results were obtained from the starfish oocytes. The cytosol of 1-MA-treated starfish oocytes can induce GVBD and polar body formation when injected into immature oocytes. Addi-

\footnotetext{
Abbreviations used in this paper: cADPr, cyclic-ADPribose; CaMKII, calmodulin dependent kinase II; CICR, calcium induced calcium release; GV, germinal vesicle; GVBD, germinal vesicle breakdown; InsP3, inositol 1,4,5trisphosphate; LAT-A, latrunculin-A; MPF, maturation promoting factor; NAADP, nicotinic acid adenine dinucleotide phosphate; PIP2, phosphatidylinositol-4,5-bisphosphate; PLC, phospholipase C; RyR, ryanodine receptor.
}

\footnotetext{
*Address correspondence to: Dr. Luigia Santella. Cell Signaling Laboratory, Stazione Zoologica Anton Dohrn, Villa Comunale I-80121 Napoli, Italy. Fax: +39-081-583-3289. e-mail: santella@szn.it
}

Published online: 27 June 2008

0214-6282/2008/\$35.00

(C) UBC Press

Printed in Spain 


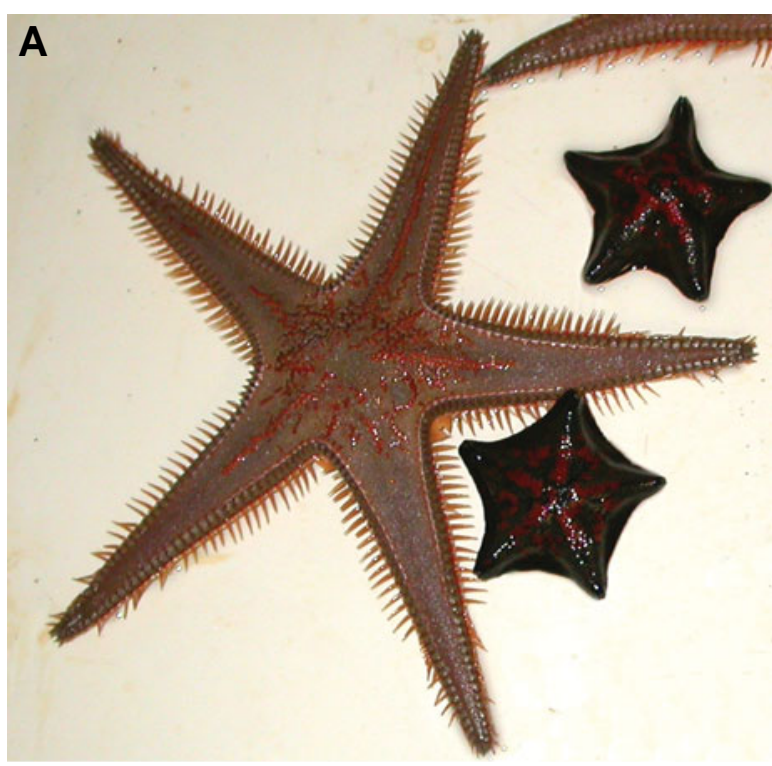

tional evidence that MPF is a Cdc2/CDK1-cyclin heterodimer was also demonstrated in starfish oocytes (Prigent and Hunt, 2004). Recently, the signaling pathway leading to MPF activation has been unraveled in several experimental systems. 1-MA activates the kinase Akt which phosphorylates and down-regulates Myt1, a membrane-associated inhibitory kinase that in turn phosphorylates Cdc2 on both threonine-14 and tyrosine-15 (Mueller et al., 1995; Okumura et al., 2002). Cdc25 is a tyrosine phosphatase that activates MPF by dephosphorylating the tyrosine residues. The activity of Cdc25 is in turn regulated by autophosphorylation and dephosphorylation, which is sensitive to protein phosphatase 1 (PP1) and protein phosphatase 2A (PP2A) (Masui, 2001; Prigent and Hunt, 2004). In starfish MPF is inactive in the cytoplasm of immature starfish oocytes, but it accumulates in the nucleus after being activated (Ookata et al., 1992). The translocation of MPF into the nucleus along with Cdc25 is thought to be essential for the final MPF activation. Studies in a number of cell types have indicated that the perinuclear/centrosomal region is the site of MPF accumulation (Bechelling et al., 2000). Recently, using cyclin B-GFP, it was shown that MPF enters the starfish nucleus starting from the animal pole side, which is the location of the centrosomes (Terasaki et al., 2003). The timing of its accumulation in the nucleus is consistent with its proposed role in disassembling the nuclear envelope, as the event takes place after the phosphorylation of the nuclear pore complexes (Macaulay et al., 1995). MPF may also play a role in chromosome condensation as was demonstrated by its periodic appearance during the mitotic cycles in the blastomere cells of amphibian embryos (Wasserman and Smith, 1978).

\section{Roles of calcium in the maturation process of starfish oocytes}

Starfish oocytes have also been an excellent model system for studying the initial events of meiotic maturation. All observations indicated that 1-MA becomes effective in inducing oocyte maturation only if the hormone was applied outside the oocyte, suggesting that the binding of the hormone to the cell surface receptor

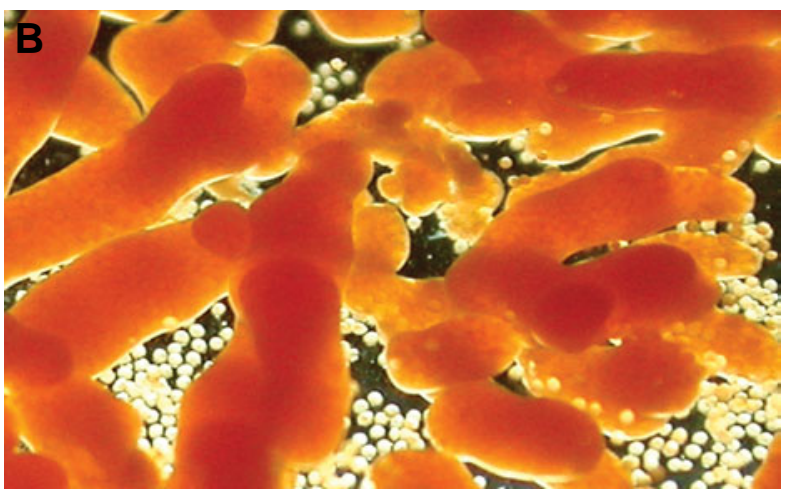

Fig. 1. Starfish provide many oocytes. (A) An adult starfish captured in the Mediterranean Sea (Astropecten aranciacus) can be as big as $50 \mathrm{~cm}$, whereas the sizes of other species of starfish (Asterina pectinifera) are about 10 to $15 \mathrm{~cm}$ in diameter. (B) Dissected gonads (orange colored tubular sac) of female A. pectinifera. Thousands of cell cycle-synchronized oocytes are easily collected and used for meiotic maturation and fertilization.

is an indispensable step (Kanatani and Hiramoto, 1970). After that, interest converged on understanding how the hormonal message could be transduced through the plasma membrane toward the effectors. The important role of $\mathrm{Ca}^{2+}$ in this maturation process had already been demonstrated in many animal species based on the external $\mathrm{Ca}^{2+}$ requirements, or an increased $\mathrm{Ca}^{2+}$ concentration in the oocyte (Guerrier et al., 1982; Meijer and Guerrier, 1984). In starfish, microinjection of $\mathrm{Ca}^{2+}$ indicator aequorin showed that the hormonal stimulation immediately results in a transient increase of intracellular $\mathrm{Ca}^{2+}$ during the first $2 \mathrm{~min}$ (Moreau et al., 1978). The $\mathrm{Ca}^{2+}$ increase occurred even in the absence of the external $\mathrm{Ca}^{2+}$, indicating that $\mathrm{Ca}^{2+}$ was released from the intracellular stores. These results were confirmed with the in vitro experiments showing that $1-\mathrm{MA}$ could trigger a $\mathrm{Ca}^{2+}$ release from the isolated plasma membrane-enriched fraction (Dorée et al., 1978; Meijer and Guerrier, 1984). However, the possibility that $\mathrm{Ca}^{2+}$ could control the MPF activity was subsequently questioned by other researchers. Indeed, studies in a number of species failed to detect changes in $\mathrm{Ca}^{2+}$ levels after hormonal stimulation of the oocytes, and they suggested that $\mathrm{Ca}^{2+}$ signaling is not absolutely required for all oocyte maturation (Eisen and Reynolds, 1984; Witchel and Steinhardt, 1990).

Over the last 13 years, our laboratory has been studying calcium signaling in the cytoplasm and the nucleus of starfish oocytes during the meiotic maturation. We have used either confocal microscopy or a sensitive CCD (charge-coupled device) camera, which are connected to the computer programs analyzing the $\mathrm{Ca}^{2+}$ mobilization patterns between the cytoplasm and the nucleus. We found that $1-\mathrm{MA}$ induces a cytosolic $\mathrm{Ca}^{2+}$ increase which is then followed by $\mathrm{Ca}^{2+}$ elevation in the nuclear compartment several seconds later. The injection of the calcium chelator BAPTA directly into the nucleus completely blocked GVBD and the continuation of the maturation process, indicating that $\mathrm{Ca}^{2+}$ plays a crucial role in triggering meiosis re-initiation (Santella and Kyozuka, 1994; Santella, 1998). The delayed rise of $\mathrm{Ca}^{2+}$ in nucleus suggests that the nuclear envelope may serve as a diffusion barrier for $\mathrm{Ca}^{2+}$, and that the nucleus may have a distinct mechanism of $\mathrm{Ca}^{2+}$ release. Later studies provided additional 
evidence in favor of the idea that the nucleus of starfish oocytes is insulated from the cytosolic $\mathrm{Ca}^{2+}$ transients (Santella et al., 2003). The $\mathrm{Ca}^{2+}$ permeability of the nuclear envelope and the mode of $\mathrm{Ca}^{2+}$ rise in the nucleus has been a subject of a vigorous debate in the literature (Santella, 1996; Santella and Carafoli, 1997; Bootman et al., 2000; Gerasimenko and Gerasimenko, 2004).

The very large size of the nucleus of the arrested oocytes has made it easier to inject directly into the nucleus the $\mathrm{Ca}^{2+}$-linked second messengers and the inhibitors of the calcium signaling pathway. In line with a role of nuclear $\mathrm{Ca}^{2+}$ in the activation of the maturation process, the delivery of the $\mathrm{Ca}^{2+}$-linked second messenger inositol 1,4,5-trisphosphate $\left(\operatorname{InsP}_{3}\right)$ into the nucleus did release starfish oocytes from the I-prophase block (Santella and Kyozuka, 1997). These findings were at variance with the previous results provided by others showing that $\mathrm{Ca}^{2+}$ release induced by cytoplasm-injected Ins $\mathrm{P}_{3}$ does not trigger the meiotic process (Picard et al., 1985). Taken together, these results added weight to the hypothesis that "nuclear" calcium signaling is indeed essential for the re-initiation of maturation.

On the other hand, the way the nucleus-injected Ins $\mathrm{P}_{3}$ elicits $\mathrm{Ca}^{2+}$ increase raises intriguing questions as to the molecular mechanism of $\mathrm{Ca}^{2+}$ release from the internal stores. After the microinjection of $\operatorname{Ins} \mathrm{P}_{3}$ into the nucleus, a very evident $\mathrm{Ca}^{2+}$ increase started at the point of the $\mathrm{Ins}_{3}$ delivery and propagated to the entire nucleoplasm. The nuclear $\mathrm{Ca}^{2+}$ increase declined approximately after $20 \mathrm{sec}$, but the $\mathrm{Ca}^{2+}$ level failed to reach the baseline and remained elevated for the entire duration of the experiment (Santella et al., 2003). The fact that the $\mathrm{Ca}^{2+}$ concentration in the nucleoplasm did not return to the normal level for a long time indicates that there is no free diffusion of $\mathrm{Ca}^{2+}$ through the nuclear pore complexes (NPCs) as was suggested by others (Brini et al., 1993; Gerasimenko et al., 1995; Perez-Terzic et al., 1997). The criticism that the injection of Ins $P_{3}$ may have brought contaminating $\mathrm{Ca}^{2+}$ into the nucleus was proven invalid by the different kinetics of the $\mathrm{Ca}^{2+}$ increase following the delivery of 1 $\mathrm{mM} \mathrm{Ca}^{2+}$ instead of InsP $\mathrm{P}_{3}$. In this case, the $\mathrm{Ca}^{2+}$ signal declined and disappeared completely in about $40 \mathrm{sec}$. Then, it is evident that Ins $\mathrm{P}_{3}$, which is known to act on its receptors on the endoplasmic reticulum, liberates $\mathrm{Ca}^{2+}$ in the nucleoplasmic compartment independent of the cytosolic $\mathrm{Ca}^{2+}$ increase (Santella et al., 2003). In line with a nucleoplasmic $\mathrm{Ca}^{2+}$ storage and release, the nucleus of the epithelial cells was shown to contain a reticular network that is continuous with the endoplasmic reticulum and the nuclear envelope. Photoactivation of caged $\mathrm{Ins}_{3}$ in the nucleoplasmic reticular structures resulted in small increases of $\mathrm{Ca}^{2+}$, suggesting that the nuclear network expresses functional InsP $\mathrm{P}_{3}$ receptors (Echevarría et al., 2003). These results are in agreement with the previous data showing that $\mathrm{Ca}^{2+}$ can be released from the nuclear tubular structures in several cell types (Lui et al., 1998), and that the antibodies against Ins $\mathrm{P}_{3} \mathrm{R} 2$ interact with them (Laflamme et al., 2002). Besides the $\operatorname{Ins}_{3}$ receptors, functional ryanodine receptors (RyRs) were observed on the invaginations of the nuclear envelope and the nucleus-penetrating endoplasmic reticulum of the striated muscle cells (Marius et al., 2006). The type 1 RyR is also expressed on intranuclear extensions of the sarcoplasmic reticulum of a skeletal muscle derived cell line (Marius et al., 2006). In the immature oocytes of starfish, however, the GV generally lacks Ins $\mathrm{P}_{3} \mathrm{R}$ (Iwasaki et al., 2002), and the anti-Ins $\mathrm{P}_{3} \mathrm{R}$ immunogold staining did not decorate the inner membrane of the GV in starfish oocytes (Santella and Kyozuka, 1997). The GV of immature starfish nonetheless released $\mathrm{Ca}^{2+}$ in response to the injected InsP ${ }_{3}$ (Santella et al., 2003). Hence, the molecular detail of $\mathrm{Ca}^{2+}$ release in the nucleus of starfish is still an open question, and it is even conceivable that $\operatorname{Ins}_{3}$ might have an alternative target or pathway to release $\mathrm{Ca}^{2+}$.

Ins $\mathrm{P}_{3}$ is not the only second messenger that releases $\mathrm{Ca}^{2+}$ inside the nucleus. The nucleus of starfish oocyte can also respond to cyclic ADP-ribose (cADPr) and liberate $\mathrm{Ca}^{2+}$. cADPr is an endogenous metabolite of $\beta-\mathrm{NAD}^{+}$with a potent $\mathrm{Ca}^{2+}$-mobilizing activity. The $\mathrm{Ca}^{2+}$ releasing activity of $\mathrm{NAD}^{+}$was first discovered in sea urchin homogenates, but the response required a characteristic delay. Later studied showed that this delay was attributable to enzymatic conversion of $\beta-\mathrm{NAD}^{+}$by ADP-ribosyl cyclase (Lee, 2002). Cross-desensitization studies with ryanodine and caffeine indicated that cADPr releases $\mathrm{Ca}^{2+}$ via a ryanodinesensitive calcium-induced-calcium-release (CICR) mechanism through the activity of a soluble protein (Clapper et al., 1987). Caged cADPr injected into starfish nuclei can elevate nuclear $\mathrm{Ca}^{2+}$ after its activation with UV light (Santella and Kyozuka, 1997). The nuclear $\mathrm{Ca}^{2+}$ transients induced by cADPr often showed an oscillatory character, and the peak-to-peak intervals of the repetitive spikes ranged 5 to $10 \mathrm{~min}$. This observation implies that functional RyRs may reside in the nucleus of immature oocytes. The presence of functional RyRs in the nucleus was proven true more recently in other cell types (Marius et al., 2006).
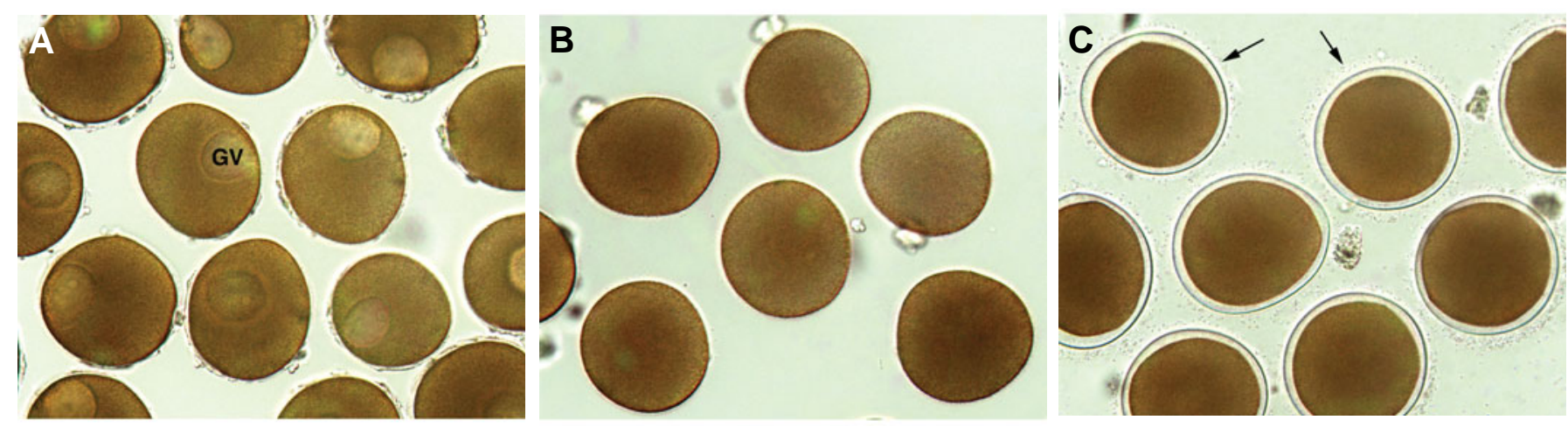

Fig. 2. Starfish oocytes exhibit reliable in vitro fertilization. (A) Immature oocytes are characterized by the big nucleus called the germinal vesicle (GV) near the animal pole. (B) In the presence of 1-methyladenine, oocytes undergo meiotic maturation. The GV is now mixed with the cytoplasm and no longer visible. (C) Successful fertilization induces elevation of the vitelline envelope (arrows), thus preventing polyspermy. 
Aside from the $\mathrm{Ca}^{2+}$ releasing intracellular channels, it has long been noted that nucleus contains phospholipase $\mathrm{C}$ (PLC) and other components for producing Ins $_{3}$ (Cocco et al., 1994; Divecha et al., 1991), as well as and the cADPr-producing enzymes in the inner membrane of the nuclear envelope (Adebanjo et al., 1999). Taken together, these observations suggest that the nucleus contains intrinsic and autonomous capacity for intranuclear mobilization of $\mathrm{Ca}^{2+}$.

$\mathrm{Ca}^{2+}$ increases during the maturation of starfish oocytes are temporally and spatially associated with the GVBD. Besides the initial $\mathrm{Ca}^{2+}$ burst, our laboratory has detected $\mathrm{Ca}^{2+}$ signals for the first time in the perinuclear area a few minutes before the breakdown of nuclear envelope (Lim et al., 2003). The spatiotemporal pattern of this $\mathrm{Ca}^{2+}$ release coincided with the increased sensitivity of the $\mathrm{Ca}^{2+}$ stores to Ins $\mathrm{P}_{3}$, which always starts at the animal hemisphere (where the nucleus is located) about 12 or 17 minutes after the addition of 1-MA, depending on the species used (see below). Starfish oocytes have been well suited for the visualization of the perinuclear $\mathrm{Ca}^{2+}$ changes by analyzing the ratio between the fluorescence of the $\mathrm{Ca}^{2+}$-sensitive dye (Oregon Green 488 BAPTA-1) and that of the $\mathrm{Ca}^{2+}$-insensitive internal control dye (rhodamine). Both fluorescent dyes are conjugated to dextran ( $\mathrm{Mw}=70,000 \mathrm{Da}$, so that they cannot cross the intact nuclear envelope) and co-injected prior to the addition of 1-MA. Since the rhodamine control distinguishes nonspecific contributions such as the ones provoked by the contraction of the oocytes that may occur before GVBD, this analysis allowed precise evaluation of the real changes in the intracellular $\mathrm{Ca}^{2+}$ concentration. The evidence that the $\mathrm{Ca}^{2+}$ increase just precedes GVBD was provided by the subsequent entry of the dyes into the nucleoplasm as a result of the breakdown of the nuclear envelope (Lim et al., 2003). These findings were in line with the data from the early sea urchin embryos, where the entry into the mitosis required triggering of perinuclear $\mathrm{Ca}^{2+}$ transient before the nuclear envelope breakdown (Poenie et al., 1985; Wilding et al., 1996). Regarding the initial $\mathrm{Ca}^{2+}$ burst, a recent contribution has suggested that the early $\mathrm{Ca}^{2+}$ transient increase following 1-MA application might directly trigger MPF activation. The inhibition of the $\mathrm{Ca}^{2+}$ increase with a chelator TMB-8 also inhibited MPF, GVBD and the subsequent chromosome condensation in Asterina pectinifera oocytes (Tosuji et al., 2007). The experimental evidence for the two $\mathrm{Ca}^{2+}$ signals occurring in the first few minutes of 1-MA stimulation, and before the GVBD, supports the idea that $\mathrm{Ca}^{2+}$ is indeed a universal activator of both the mitotic and the meiotic cell cycles.

\section{Calcium targets during oocyte maturation}

Experiments were then performed to identify potential calcium targets among the calcium-activated proteins that may play a role in the maturation of starfish oocyte. Calmodulin (CaM) is a $\mathrm{Ca}^{2+}$ binding protein with EF hand motif and is considered as the key molecule to transduce $\mathrm{Ca}^{2+}$ signals either by activation of target enzymes or by modulation of protein/protein interactions in the cytoplasm and the nucleus (Carafoli et al., 2001). Nuclear $\mathrm{Ca}^{2+}$ also plays an important role in regulating gene expression by several distinct pathways. While the trans-activating properties of transcription factors such as CREB (cAMP-responsive element binding protein) are regulated by $\mathrm{Ca}^{2+}$-dependent kinases and phosphatases (Hardingham et al., 2001), $\mathrm{Ca}^{2+}$ can also directly bind to a transcription regulator such as DRE-antagonist modulator (DREAM) and modulate gene expression (Carrión et al., 1999).

In starfish, following the identification of CaM and several CaMbinding proteins, the role of $\mathrm{CaM}$ in the regulation of the meiotic cycle has been investigated using CaM antagonists. Several inhibitors and antagonists could suppress 1-MA-induced maturation (Mejier and Guerrier, 1984). Experiments were performed to establish whether a nuclear CaM pool is relevant to the progression of the meiotic cycle. CaM antagonists, antibodies, and the inhibitory peptide corresponding to the CaM-binding domain of myosin-light-chain kinase were directly injected into the nucleus of prophase-arrested starfish oocytes. While the CaM antagonists only delayed GVBD, the peptide inhibitor and the antibodies completely inhibited it. The antibodies also suppressed the nuclear $\mathrm{Ca}^{2+}$ spikes that were induced by photoactivation of caged cADPr in the nucleus. Immunofluorescence staining of isolated starfish oocyte nuclei with CaM antibodies showed that CaM is localized in the nuclear envelope and in the nucleolus, while immunogold labeling studies revealed that the aggregates of $36-\mathrm{kDa}$ protein and $\mathrm{CaM}$ are present in the nuclear matrix as heterogeneous ribonucleoprotein particles (hnRNP). 1-MA treatment made these hnRNP disappear from the nucleoplasm and caused translocation of $\mathrm{CaM}$ and its associated $36-\mathrm{kDa}$ protein to the cytoplasm before the breakdown of the nuclear envelope (Santella and Kyozuka, 1997a). Taken together, these observations strongly suggested that a CaM-dependent step in the nucleus is involved in the initiation of the maturation process. It is now known that the nuclear activation of MPF is mediated by translocated Cdc25 which in turn is activated by a calmodulin-dependent protein kinase II (CaMKII) in the nucleus (Kishimoto, 1999; Lim et al., 2003). A role for CaMKII in promoting GVBD and the metaphaseanaphase transition has also been demonstrated with the maturing mammalian oocytes (Su and Eppig, 2002).

\section{Development of the $\mathrm{Ca}^{2+}$-releasing systems during maturation of starfish oocytes}

During the meiotic maturation, a starfish oocyte develops its ability to be successfully activated by a fertilizing spermatozoon. Data have been documented on the morphological changes that accompany maturation, and it has been reported that the electrophysiological properties of the oocyte are also changed in this process (Meijer and Guerrier, 1984).

The immature starfish oocyte manifests polarized cell morphology with its large nucleus located closer to the plasma membrane of the animal hemisphere. The cytoskeletal organization of the animal pole is also different from that of the other hemisphere. In addition, the cortical region of the oocyte differs from the inner cytoplasm in that the F-actin filaments are orderly clustered beneath the plasma membrane and form a visibly distinct cortical layer. The 1-MA treatment induces morphological changes at both cortical and nuclear regions. Scanning EM and immunofluorescence microscopic studies have established that 1-MA stimulates the transient appearance of prominent spike-like protrusions on the oocyte surface due to the rapid assembly of the actin filaments in the inner-core bundles of microvilli (Schroeder and Stricker, 1983; Otto and Schroeder, 1984). Following these 
early events, 1-MA subsequently induces more massive reorganization of the endoplasmic reticulum (ER), the major cytoplasmic $\mathrm{Ca}^{2+}$ store that contributes to the development of a normal $\mathrm{Ca}^{2+}$ response at fertilization. The purpose of this process, hallmarked by the breakdown of nuclear envelope and the intermixing of the nucleoplasm with the cytoplasm, is to adapt the cells to the subsequent fertilization event. In the end of the maturation process, the intracellular $\mathrm{Ca}^{2+}$ release is facilitated, and the $\mathrm{Ca}^{2+}$ induced exocytosis of cortical granules leads to elevation of the vitelline layer (fertilization envelope) to prevent polyspermy (Longo et al., 1995; Santella et al., 1999).

With starfish oocytes, it was first documented that the maturation-induced structural reorganization of the ER is linked to the facilitated $\mathrm{Ca}^{2+}$ signaling in fertilization. The visualization of the ER membranes by injecting an oil drop saturated with the fluorescent lipophilic dye Dil (Jaffe and Terasaki, 1994) has made it possible to easily observe the changes of the ER structures during the 1-MA-induced meiotic maturation. The dramatic structural changes of ER could explain why sperm entry produces more $\mathrm{Ca}^{2+}$ release in the mature eggs than in the immature oocytes (Chiba et al., 1990). The ability of an egg cell to release more $\mathrm{Ca}^{2+}$ after maturation was also found in other species. Maturationinduced formation of ER clusters in marine worm eggs was shown to be associated with the ability to elicit a proper $\mathrm{Ca}^{2+}$ response at fertilization (Stricker et al., 1998). Similar ER clusters, which were not present at the GV-stage, also appeared in the mouse egg cortex following the meiotic maturation (Mehlmann et al., 1995). Since the available evidence at that time indicated that the $\mathrm{Ca}^{2+}$ release at fertilization was mediated by $\operatorname{InsP}_{3}$, (Swann and Whitaker, 1986), the $\mathrm{Ca}^{2+}$-releasing effect by InsP $\mathrm{P}_{3}$ was investigated before and after the maturation process. It was found that the response of the $\mathrm{Ca}^{2+}$ stores to the same amount of Ins $\mathrm{P}_{3}$ was much higher in the oocytes after maturation (Chiba et al., 1990; Chun and Santella 2007). Such increased sensitivity of the InsP receptors to $I n s P_{3}$ was not due to the increased charge of the $\mathrm{Ca}^{2+}$ stores during the maturation process nor to overexpression or redistribution of the Ins $_{3}$ receptors (Iwasaki et al., 2002). The Ins $\mathrm{P}_{3}$-sensitive $\mathrm{Ca}^{2+}$ stores were already fully replenished in immature starfish oocytes so that $\operatorname{InsP}_{3}$ would have induced comparable $\mathrm{Ca}^{2+}$ release from immature and mature oocytes (Chiba et al., 1990; Lim et al., 2003). Subsequent works in other species were aimed at the differential expression and redistribution of the $\mathrm{Ins}_{3}$ receptors during the maturation process. Indeed, the increased sensitivity to $\operatorname{InsP}_{3}$ between the $\mathrm{GV}$ stage and prometaphase of the first meiosis in mammalian oocytes (Fujiwara et al., 1993) correlated with the increased number of the cortical InsP ${ }_{3}$ receptors (Mehlmann et al., 1996). In addition, heterogeneity and the differential expression level of Ins $\mathrm{P}_{3} \mathrm{R}$ isoforms during maturation and fertilization may add to the functional fine tuning of the InsP $\mathrm{P}_{3}$ receptor complex (Parrington et al., 1998; Fissore et al., 1999; Malcuit et al., 2005).

In starfish, $\mathrm{RyR} \mathrm{Ca}^{2+}$ channels also produce characteristically distinct $\mathrm{Ca}^{2+}$ release patterns after the oocyte maturation process. While RyR agonists include ryanodine, cADPr and caffeine, cADPr is the major endogenous agonist of the receptor (Lee and Aarhus, 1991). The pre-injection of the starfish oocytes with specific antagonist of the cADPr/ryanodine receptors $8 \mathrm{NH}_{2} \mathrm{CADPr}$ completely blocked the $\mathrm{Ca}^{2+}$ response following the $\mathrm{CADPr}$ uncaging, confirming that RyR mediates the $\mathrm{Ca}^{2+}$ releasing effect of cADPr. RyR mediates CICR, and it modulates the $\mathrm{Ca}^{2+}$ signals following sea urchin fertilization (Galione et al., 1993). The spatiotemporal aspects of the cADPr-dependent $\mathrm{Ca}^{2+}$ release have been also explored in immature and 1-MA-matured starfish oocytes. In immature Astropecten aranciacus oocytes, uncaging of the injected cADPr produced multiple patches of $\mathrm{Ca}^{2+}$ release in the cortical region. The $\mathrm{Ca}^{2+}$ signals then spread centripetally from these initial points of increase to the entire cell. Both the cortical $\mathrm{Ca}^{2+}$ patches and the global $\mathrm{Ca}^{2+}$ wave induced by cADPr are due to the $\mathrm{Ca}^{2+}$ release from the intracellular stores, as indicated by the lack of effect of external $\mathrm{Ca}^{2+}$. In mature oocytes, the photoactivation of cADPr initiates $\mathrm{Ca}^{2+}$ release in the cortex from fewer spots (one or two at most), but the $\mathrm{Ca}^{2+}$ release was greatly enhanced in comparison with the immature oocytes. The mature oocytes manifested clearly defined cortical flash in response to the uncaged cADPr. The $\mathrm{Ca}^{2+}$ burst is then followed by subsequent globalization of the wave before the elevation of the fertilization envelope. In both mature and immature oocytes, it is worth noting that cADPr initiates $\mathrm{Ca}^{2+}$ responses preferentially in the cortical areas. These results imply that the cortical region beneath the plasma membrane is generally more sensitive to cADPr than the inner cytoplasm. However, the precise role of cADPr in shaping the intracellular $\mathrm{Ca}^{2+}$ waves during fertilization is not clear. The sequence of $\mathrm{Ca}^{2+}$ responses induced by cADPr in mature oocytes strongly mimicked those seen at fertilization, suggesting that CADPr and ryanodine receptors might play a role in the initial $\mathrm{Ca}^{2+}$ signal at fertilization. However, the pre-injection of the cADPr antagonist did not inhibit the propagation of the sperm-induced $\mathrm{Ca}^{2+}$ wave, indicating that cADPr is not involved in the CICR mechanism in these oocytes species. This suggestion is further supported by the lack of $\mathrm{Ca}^{2+}$ elevation following the uncaging of cADPr in the Japanese species (Asterina pectinifera) of starfish oocytes (Nusco et al., 2006).

Very recently, the development of the RyR- or Ins $\mathrm{P}_{3}$ receptordependent $\mathrm{Ca}^{2+}$-releasing systems was investigated during the in vitro maturation of sea urchin oocytes. By comparing the $\mathrm{Ca}^{2+}$ response induced by $\mathrm{cADPr}$, InsP $\mathrm{P}_{3}$ or the sperm, it has been demonstrated that the sensitivity to cADPr (RyR pathway) is much higher than that of InsP $\mathrm{P}_{3}$ whose response is established considerably later (Miyata et al., 2006). By contrast, in mammalian oocytes, the density of the RyR is 30 - to 100 -fold lower than that of the Ins $\mathrm{P}_{3} \mathrm{R}$, implying that the $\mathrm{Ca}^{2+}$ signals in meiotic maturation is mostly attributed to $\operatorname{Ins}_{3} R$. These results agree with the suggestion that, although ryanodine receptors are present and functional in mammalian oocytes, the release of $\mathrm{Ca}^{2+}$ from this store is not essential for the sperm-induced egg activation (He et al., 1997).

We have found that a newly established second messenger nicotinic acid adenine dinucleotide phosphate (NAADP) also contributes to the intracellular $\mathrm{Ca}^{2+}$ release in starfish oocytes (Santella et al., 2000). In NAADP, the nicotinamide ring of nicotinamide adenine dinucleotide phosphate (NADP) is replaced by nicotinic acid. Ever since its discovery as a $\mathrm{Ca}^{2+}$-mobilizing molecule in sea urchin egg homogenates, NAADP has exhibited distinct pharmacological properties (Clapper et al., 1987). Depletion of $\mathrm{Ca}^{2+}$ stores from endoplasmic reticulum (ER) in sea urchin egg homogenates using thapsigargin, a sarcoplasmic/ER calcium ATPase (SERCA) pump inhibitor, does not prevent NAADPmediated release of $\mathrm{Ca}^{2+}$ from these preparations. Hence, the 

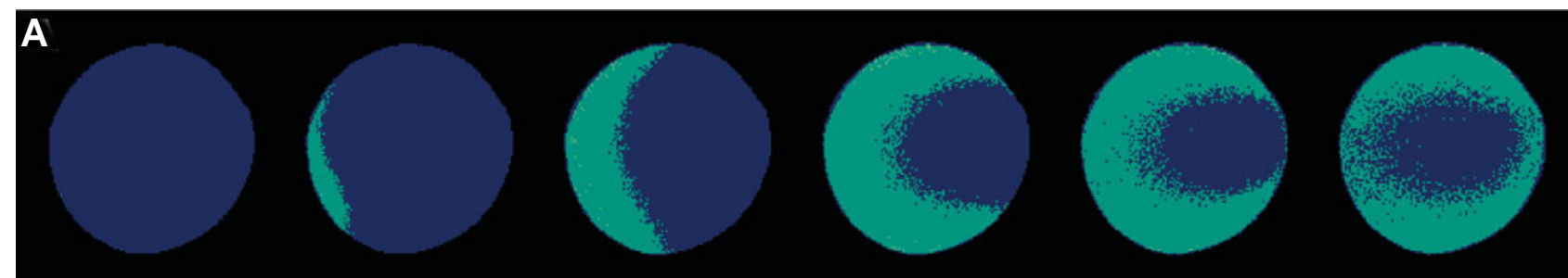

B
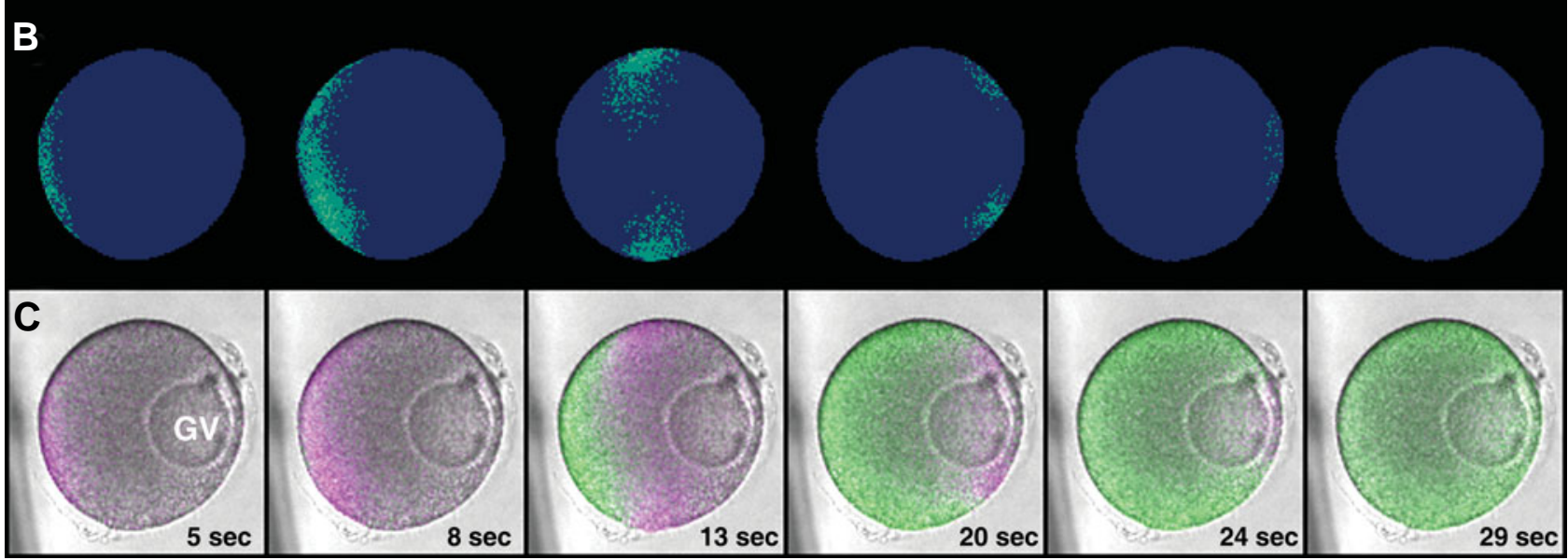

Fig. 3. Meiotic maturation of starfish oocytes is signalled by quick mobilization of intracellular $\mathbf{C a}^{2+}$. Within 1-2 min after the addition of 1methyladenine, intracellular $\mathrm{Ca}^{2+}$ starts to be released from the vegetal hemisphere of the oocytes. (A) The relative fluorescence pseudo-colored images of the $\mathrm{Ca}^{2+}$ wave. (B) The relative pseudo-colored images of the instantaneous $\mathrm{Ca}^{2+}$ release represented by the formula $F_{\text {inst }}=\left[\left(F_{t^{-}} F_{t^{-}}\right) / F_{t^{-}}\right]$. (C) The merged views of the transmission micrograph and the two relative pseudo-colored images acquired in $(A)$ and $(B)$. Green fluorescent $C a^{2+}$ dye delineates diffusion of intracellular $\mathrm{Ca}^{2+}$, whereas the momentary increment of $\mathrm{Ca}^{2+}$ was depicted in pink to show the actual sites of instantaneous $\mathrm{Ca}^{2+}$ release.

NAADP-sensitive $\mathrm{Ca}^{2+}$ stores are not located in the ER. These findings are also in line with the distribution profile of NAADPmediated $\mathrm{Ca}^{2+}$ stores in cell fractionation experiments, which did not co-migrate with the ER fraction (Genazzani and Galione, 1996). In starfish oocytes, one peculiar aspect of the NAADPinduced $\mathrm{Ca}^{2+}$ response is that the cortical $\mathrm{Ca}^{2+}$ mobilization by uncaged NAADP is linked to the extracellular $\mathrm{Ca}^{2+}$ (Nusco et al., 2002). The NAADP-induced $\mathrm{Ca}^{2+}$ mobilization becomes more dependent on the external $\mathrm{Ca}^{2+}$ as the starfish oocyte is matured by $1-M A$, raising the possibility that the NAADP-sensitive $\mathrm{Ca}^{2+}$ pool might be shifted toward the plasma membrane during this process (Santella et al., 2000; Santella, 2005).

\section{Maturation-promoting factor and the increased sensi- tivity of Ins $\mathrm{P}_{3}$ receptors}

In starfish, the whole process leading to GVBD in the 1-MAtreated oocytes can be divided into three steps with regard to the changes in MPF activities. In the first stage, the activation by 1-MA produces a small amount of active MPF in the cytoplasm which increases due to its autocatalytic amplification. Then, MPF accumulates in the nucleus before GVBD takes place (Picard and Dorée, 1984). Finally, the MPF activity is boosted further by Cdc25 inside the GV. Indeed, MPF is completely absent in the GV of the starfish oocytes before the 1-MA treatment as determined by confocal microscopy. After the onset of GVBD, however, higher intensity of the anti-cyclin B immunofluorescence was observed in the nucleus than in the cytoplasm (Ookata et al., 1992). It has been suggested that MPF plays a role in the modification of the centrosome, which eventually leads to the formation of the mitotic spindle (Bailly et al., 1989).

Apart from the role of MPF as a decisive factor that liberates the oocytes from the prophase block and induces the complete meiotic maturation, MPF appears to modulate ER reorganization and $\mathrm{Ca}^{2+}$ signaling in both maturing and fertilized oocytes (Chun and Santella, 2007). Pharmacological and biochemical assays combined with in vivo confocal imaging have demonstrated a functional relationship between MPF activities and the ER cluster formation. While maturing oocytes manifested higher MPF activity and more extensive clusters formation, fertilized eggs undergoing ER cluster disassembly showed concomitant drop of MPF activity (Stricker and Smythe, 2003). On the other hand, metaphase II-arrested oocytes maintain high levels of MPF activity. At fertilization, the transition to anaphase is stimulated by the sperminduced increase in intracellular $\mathrm{Ca}^{2+}$. This increase of $\mathrm{Ca}^{2+}$ results in the destruction of cyclin B1 (the regulatory subunit of MPF) and the kinase inactivation, which eventually leads to egg activation (Marangos and Carroll, 2004). Hence, in large part, the downstream effect of intracellular $\mathrm{Ca}^{2+}$ signaling may be mediated through MPF.

Conversely, MPF activity can also affect the intracellular mobilization of $\mathrm{Ca}^{2+}$. It has been shown that MPF activity can influence the sperm-triggered calcium oscillations in ascidian and mammalian eggs (Levasseur and McDougall, 2000; Deng and Shen, 2000; Marangos and Carroll, 2004). In starfish oocytes, the experiments with the MPF inhibitor roscovitive have demonstrated that the increased InsP $\mathrm{P}_{3}$ response during meiotic maturation is strongly correlated with the MPF activity. While roscovitine inhibited GVBD and 1-MA-induced $\mathrm{Ca}^{2+}$ signals, injection of active MPF into immature oocytes produced $\mathrm{Ca}^{2+}$ signals and 
frequent GVBD. Furthermore, the global propagation of $\mathrm{Ca}^{2+}$ signals takes place only when $\operatorname{lns}_{3}$ was photoactivated well after the full establishment of MPF activity, e.g. 30 min after hormonal stimulation (Lim et al., 2003). While the nuclear amplification of MPF may be mediated by the CaMKII-linked activation of Cdc25 (Patel et al., 1999), it is not known whether the increased InsP ${ }_{3}$ sensitivity of the $\mathrm{Ca}^{2+}$ pool is due to the direct (or indirect) phosphorylation of $\operatorname{InsP}_{3}$ receptors by MPF. For this reason, search for the other MPF targets have been made (see below).

\section{F-actin and actin-binding proteins modulate the re- lease of $\mathrm{Ca}^{2+}$ during oocyte maturation}

In the past few years, additional information has been accumulated on the spatiotemporal pattern of the 1-MA-induced $\mathrm{Ca}^{2+}$ signals. We have observed that the $\mathrm{Ca}^{2+}$ signal always initiated at the certain side of the oocytes, the vegetal hemisphere (Fig. 3). The $\mathrm{Ca}^{2+}$ wave propagates to the cytoplasm in a shape of cortical half moon and eventually reaches the nucleus at the opposite side within 15-20 sec (Santella et al., 2003). By analyzing the incremental changes of the $\mathrm{Ca}^{2+}$ rise to map the actual site of instantaneous $\mathrm{Ca}^{2+}$ release, we have noticed that the 1-MA-induced $\mathrm{Ca}^{2+}$ increase is exclusively localized to the cortex (Moreau et al., 1978; Kyozuka et al., 2008). Combined with the fact that the $\mathrm{Ca}^{2+}$ wave specifically starts from the vegetal hemisphere, where InsP receptors are less concentrated, these observations raised a possibility that additional factors intrinsic to the cortex may also contribute to the $\mathrm{Ca}^{2+}$ releasing process in response to 1-MA.

One of the elements that add to the asymmetry of the oocyte is the actin cytoskeleton. In oocytes, actin filaments are not randomly distributed inside the cell. First of all, dense networks of actin filaments are preferentially concentrated in the subplasmalemmal zone of the oocyte, exactly the same area where 1-MA-induced $\mathrm{Ca}^{2+}$ signals propagate. This cortex-specific F-actin layer is peculiarly absent in the space between the GV and the plasma membrane, the animal pole. Indeed, it is through this "corridor" that the two polar bodies are extruded at the later stage of meiosis. Hence, it is possible that such asymmetric organization of the actin cytoskeleton may be accountable for the vegetal hemisphere-specific initiation of the $\mathrm{Ca}^{2+}$ signals and their cortex-mediated propagation. In support of the idea that the subplasmalemmal actin cytoskeleton may play a role in $\mathrm{Ca}^{2+}$ signaling, the 1-MA-induced $\mathrm{Ca}^{2+}$ release takes place exactly at the same moment when the actin bundles on the cell surface (microvilli) are undergoing dynamic remodeling (Schroeder and Stricker, 1983; Otto and Schroeder, 1984).

In line with this, we have recently observed that the rearrangement of the actin cytoskeleton can strongly modulate $\mathrm{Ca}^{2+}$ signals during the maturation and fertilization processes of starfish oocytes (Lim et al., 2002; Lim et al., 2003: Nusco et al., 2006). The first evidence that cortical actin plays a role in starting and propagating $\mathrm{Ca}^{2+}$ came from the experiments performed in our laboratory. In matured oocytes of starfish, incubation with the actin-depolymerizing drug latrunculin-A (LAT-A) induced a massive calcium mobilization and the consequential discharge of the cortical granules, which led to the elevation of the fertilization envelope (Lim et al., 2002). These surprising results were observed even without the addition of $\mathrm{Ca}^{2+}$-inducing second messengers. The initial pattern of the LAT-A-induced $\mathrm{Ca}^{2+}$ release was reminiscent of the fertilization process. The $\mathrm{Ca}^{2+}$ release starts at a circumscribed site on the oocyte surface, and then expanded to the cortical layer before propagating rapidly to the center of the oocyte and eventually producing $\mathrm{Ca}^{2+}$ oscillations. Initially, it was suggested that the $\mathrm{Ca}^{2+}$ spreading from the cortex to the remainder of the oocyte was mediated by $\mathrm{InsP}_{3}$ receptors because the classical Ins $\mathrm{P}_{3}$ receptor inhibitor, heparin, can completely abolish the LAT-A-induced $\mathrm{Ca}^{2+}$ mobilization (Lim et al., 2002). Whatever may be its molecular mechanism, LAT-A-induced $\mathrm{Ca}^{2+}$ release also depends on the maturation-related cytological changes of the oocyte. In immature oocytes, LAT-A can only induce a gradual increase of $\mathrm{Ca}^{2+}$. In this regard, it is worth noting that starfish undergoes drastic rearrangement of actin filaments during 1-MA-induced meiotic maturation (Fig. 4). Interestingly, the LAT-A-induced $\mathrm{Ca}^{2+}$ release always starts at the animal hemisphere at the time when the increased sensitivity to InsP $\mathrm{P}_{3}$ was established in response to 1-MA. While these results implicate the $\mathrm{InsP}_{3}$-sensitive stores into the LAT-A-induced $\mathrm{Ca}^{2+}$ signaling, it was also suggested that the rearrangement of the actin cytoskeleton may be the downstream target of MPF-mediated phosphorylation events (Lim et al., 2003). In support of the idea that reorganization of cytoskeleton may be caused by active MPF, MPF is associated with microtubules through microtubuleassociated proteins (MAPs) (Ookata et al., 1993). Rendering more significance to the role of cytoskeleton in regulating the signal transduction by 1-MA, immunofluorescence data have shown that the G-protein $\beta \gamma$ subunits are associated not only with the plasma membrane but also with the cytokeratin intermediate filaments in the cytoplasm. The activation of MPF and oocyte maturation by injected $\beta \gamma$ subunits in the perinuclear region gives them functional significance as cytoplasmic effectors transducing 1-MA signal (Chiba et al., 1995).

As mentioned earlier, starfish oocytes begin to respond to 1MA with two visible changes: the $\mathrm{Ca}^{2+}$ burst and dynamic reorganizations of actin bundles in microvilli. Since these two events are simultaneously taking place a few minutes after adding hormone, these phenomena provided us with an optimal opportunity to study the relationship between $\mathrm{Ca}^{2+}$ signaling and the cortical actin cytoskeleton. This is even before any significant structural changes takes place in ER. Based on the observation that the classical agents blocking either Ins: $\mathrm{P}_{3}$-producing enzyme (U73122) or $\operatorname{InsP}_{3}$ receptor (heparin) can completely suppress the 1-MA-induced intracellular $\mathrm{Ca}^{2+}$ release, this process was initially presumed to be mediated by $\operatorname{InsP}_{3}$. However, further analysis of the oocyte revealed that both U-73122 and heparin produce drastic rearrangement of cortical actin layers, raising the possibility that the inhibitory effect of these agents might have been caused by the changes of actin cytoskeleton at the very site where $\mathrm{Ca}^{2+}$ signal is produced. In support of this idea, all the tested agents that promote unidirectional disassembly (LAT-A) or assembly of actin filaments (jasplakinolide) at the cortical layer of oocytes have severely inhibited the 1-MA-induced $\mathrm{Ca}^{2+}$ release (Kyozuka et al., 2008). Conversely, the 1-MA-induced $\mathrm{Ca}^{2+}$ release can be also facilitated by the agent that reorganizes actin cytoskeleton. Cofilin, a member of the actin-depolymerizing factor (ADF) family, can enhance the $\mathrm{Ca}^{2+}$ signals in the 1-MA-treated starfish oocytes by nearly two-fold (Nusco et al., 2006). Taken together, these results indicate that the actin cytoskeleton is a key player in modulating the $\mathrm{Ca}^{2+}$ release in response to 1-MA. 
Fig. 4. Changes of the actin cytoskeleton during the meiotic maturation and fertilization of starfish oocytes. Confocal miscroscopic images of live oocytes pre-injected with Alexa-568-conjugated phalloidin. (A) Immature oocytes manifest a dense network of actin filaments underneath the plasma membrane and inside the cytoplasm. The nucleus (germinal vesicle, GV) is phalloidin-negative at this stage. (B) Actin cytoskeleton in the same oocyte after $1 \mathrm{~h}$ treatment with 1-methyladenine. It is noticeable that the actin cytoskeleton in the cortical region and the cytoplasm is now drastically reduced. (C) Fast reorganization of the actin cytoskeleton at the very moment of sperm internalization. The sperm is pulled into the egg by the actin fibers from the fertilization cone (arrow). (D) Higher magnification view of the cortical region of an immature oocyte shows occasional occurrence of striated actin fibers (arrows), which are presumably due to the periodic association of actinbinding proteins.

Besides regulating $\mathrm{Ca}^{2+}$ release, actin may play additional role in the nucleus especially during the meiotc cell division. Very recently, it has been shown that nuclear actin network is instrumental in bringing chromosomes to the proximity of the nascent meiotic spindle in starfish oocyte. The mechanism by which spindle captures chromosomes has been exclusively attributed to microtubules. However, the finding that chromosomes move on actin filaments and not microtubules indicated a novel role for the actin cytoskeleton in the long-range transport (Lénárt et al., 2005).
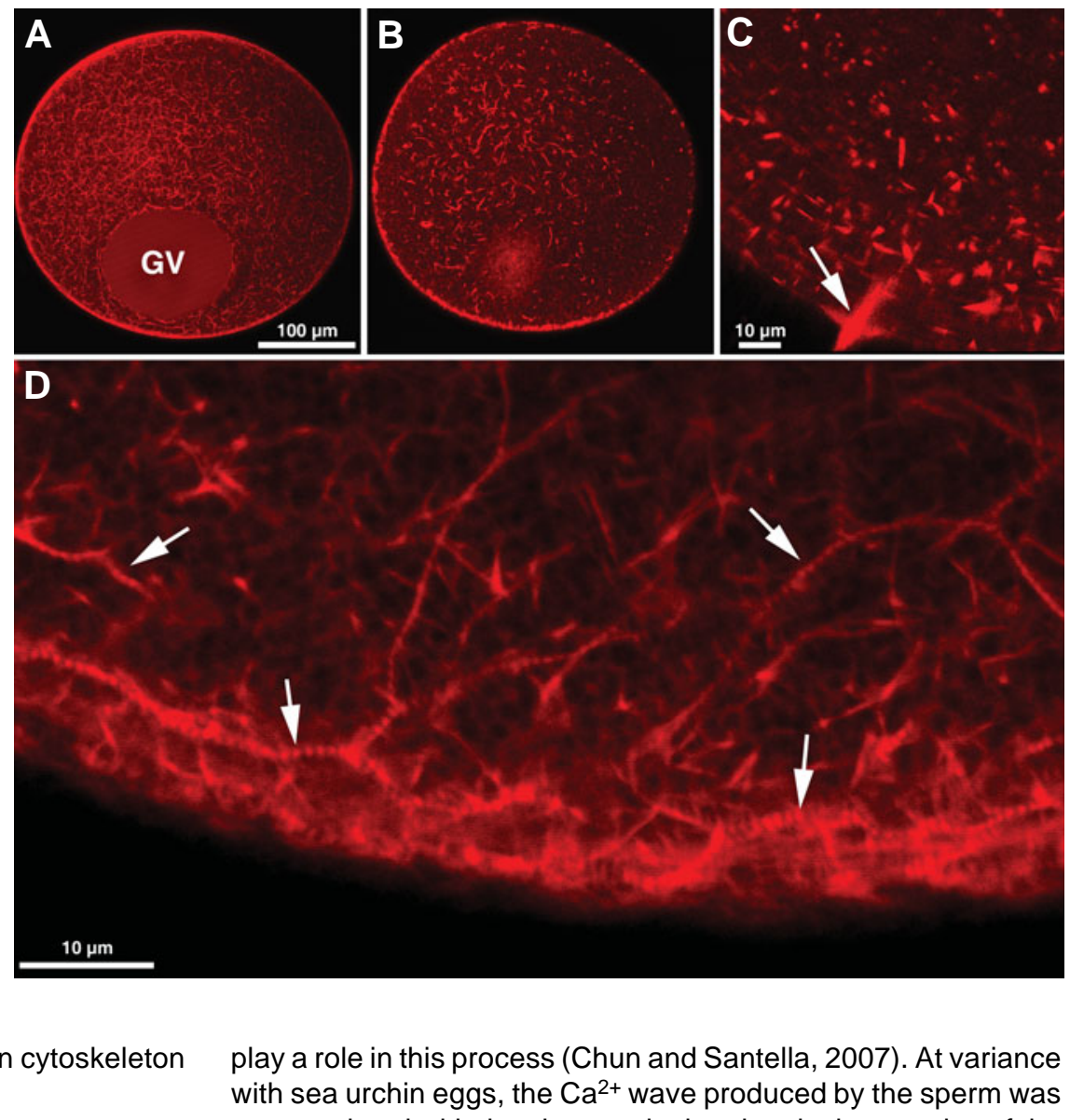

\section{Sperm-egg interaction at fertilization}

Echinoderm eggs have been a useful model for studying the ultrastructural changes at fertilization. A prerequisite for the entry of the sperm into eggs is the acrosome reaction because the egg plasma membrane can only fuse with the newly formed membrane of the acrosomal process. In sea urchin, sulfated fucoserich compounds in the jelly coat of the egg provide speciesspecificity in inducing the acrosome reaction (Hirohashi et al., 2002). Within 2-4 sec following the attachment of the fertilizing spermatozoon to the vitelline coat, a step-like depolarization occurs across the egg plasma membrane, probably due to a factor released from the acrosome in the proximity of the egg plasma membrane (Longo et al., 1986). This is followed by the fertilization potential, which is accompanied by the cortical reaction (Vacquier, 1975). In starfish, the acrosome reaction-regulated exocytotic process involves the secretion of the acrosomal content upon the contact of the sperm with the sugar components of the outer layer of the jelly coat (Nakachi et al., 2006). The first sign of sperm activation is the morphological changes of the spermatozoon that extends a long thin acrosomal process, owing to the polymerization of the acrosomal globular actin (Fig. 5). The acrosomal process could be as long as $20 \mu \mathrm{m}$, protruding from the outer border of the plasma membrane (Dan, 1960; Dale et al., 1981). At fertilization, $\mathrm{Ca}^{2+}$ signals initiate well before the sperm is physically incorporated into the egg, raising the possibility that a mode of remote control through the acrosomal process might

play a role in this process (Chun and Santella, 2007). At variance with sea urchin eggs, the $\mathrm{Ca}^{2+}$ wave produced by the sperm was not correlated with the changes in the electrical properties of the plasma membrane in starfish oocytes (Dale et al., 1981). The first detectable electrical change of the egg plasma membrane is the fertilization potential, whose rise is slower than that of the sea urchin egg. The cortical reaction initiates simultaneously with the fertilization potential before the spermatozoon is completely inside the oocyte (Dale et al., 1981). It has been a matter of continued debate in the past whether the activation of the egg requires sperm attachment or penetration into the egg (Shapiro and Eddy, 1980). Starfish oocytes have allowed us to determine the precise location of the acrosome reaction and to carefully monitor the molecular events underlying successful attachment of the spermatozoon to the plasma membrane and the initiation of the $\mathrm{Ca}^{2+}$ wave (Fig. 5).

\section{Calcium signaling during fertilization}

At fertilization, in all the species studied so far, a transient increase in the intracellular $\mathrm{Ca}^{2+}$ appears essential for reinitiating protein and DNA synthesis (Epel, 1990). The $\mathrm{Ca}^{2+}$ elevation begins at the site of sperm-egg interaction and crosses the egg as a wave (Fig. 5). This $\mathrm{Ca}^{2+}$ increase induces cortical granule exocytosis and the consequent elevation of the vitelline layer, which also begins at the point of sperm entry. Several observations have led to the conclusion that the phospholipase C (PLC)induced hydrolysis of the $\mathrm{PIP}_{2}$ and the resulting formation of $\mathrm{InsP}_{3}$ were responsible for the liberation of $\mathrm{Ca}^{2+}$ from intracellular stores (Santella et al., 2004). An increase in $\operatorname{InsP}_{3}$ and DAG (the other 
product of phosphatidylinositol 4,5-bisphosphate $\left(\mathrm{PIP}_{2}\right)$ hydrolysis) had been detected in the first $15 \mathrm{sec}$ after fertilization (Whitaker, 2006). Supporting the idea that $\operatorname{lns}_{3}$ is the messenger that promotes $\mathrm{Ca}^{2+}$ mobilization at fertilization, microinjection of neomycin (an inhibitor of $\mathrm{PIP}_{2}$ hydrolysis) prevented the sperminduced calcium transient and egg activation (Swann and Whitaker 1986). In agreement with this hypothesis, microinjection of Ins $\mathrm{P}_{3}$ induced cortical granule exocytosis and the membrane elevation as a result of a massive release of $\mathrm{Ca}^{2+}$ from intracellular stores. Thus, the role of InsP $\mathrm{P}_{3}$ and its receptors in the onset of the $\mathrm{Ca}^{2+}$ response at fertilization was reinforced by the observation that the fertilization $\mathrm{Ca}^{2+}$ waves in most species were strongly inhibited by the antagonist of the $\operatorname{InsP}_{3}$ signaling pathway such as heparin, anti-Ins $\mathrm{P}_{3} \mathrm{R}$ monoclonal antibodies and $\mathrm{Ins}_{3}$-sequestering peptides (McDougall et al., 2000; Iwasaki et al., 2002; Miyazaki et al., 1992).

However, the suggested "receptor-G-protein-PLC hypothesis" was questioned due to the lack of evidence for a sperm receptor in the plasma membrane. Complicating results were also obtained from the experiments manipulating G-proteins with toxins (cholera and pertussis toxins), in which G-protein signaling pathway may be involved in the cortical granule exocytosis, but not in the intracellular $\mathrm{Ca}^{2+}$ liberation (Turner et al., 1987; Jaffe et al., 1988). Subsequently, a pathway not involving a canonical Gprotein-linked cascade, but instead tyrosine kinases, was proposed following the finding that an increase in protein-tyrosine phosphorylation was detected $1 \mathrm{~min}$ after the activation of sea urchin eggs with sperm. Since the same increase was detected upon activation by ionomycin, it was suggested that $\mathrm{Ca}^{2+}$ itself could reciprocally stimulate the tyrosine kinase activity, completing a positive feedback loop. It was then investigated whether phospholipase $\mathrm{C} \gamma(\mathrm{PLC} \gamma)$ is involved in $\mathrm{Ca}^{2+}$ release. Western blot and immunocytochemistry indicated that $\mathrm{PLC} \gamma$ is present in cortical regions, suggesting that PLC $\gamma$ may be a part of the cascade of events leading to the calcium release in sea urchin fertilization (de Nadai et al., 1998). In starfish oocyte, PLC $\gamma$ is activated when its two src-homology ( $\mathrm{SH} 2)$ domains bind to an activated tyrosine kinase. The sperm-induced $\mathrm{Ca}^{2+}$ signal was delayed or completely blocked by the injection of $\mathrm{PLC} \gamma \mathrm{SH} 2$ domain-fusion proteins that suppress PLC $\gamma$ activation (Carroll et al., 1997). Recently, an oocyte cDNA encoding PLC $\gamma$ has been isolated from starfish, supporting that the $\mathrm{Ca}^{2+}$ response at fertilization in this species is regulated by endogenous PLC $\gamma$ (Runft et al., 2004). It being understood that $\operatorname{InsP}_{3}$ is the main actor in $\mathrm{Ca}^{2+}$ mobilization at fertilization, the proposal that the sperm introduces a cytosolic factor into the eggs that triggers InsP $\mathrm{P}_{3}$-dependent $\mathrm{Ca}^{2+}$ mobilization has been controversial for many years due to the failure to identify the molecular nature of such a "sperm factor" (Dale et al., 1985; Swann, 1990; Stricker, 1997; Kyozuka et al., 1998; Parrington et al., 2007). However, recent work in mammalian oocytes has significantly advanced our knowledge on this matter. A sperm-specific PLC $\zeta$ (zeta) isoform with distinctive enzymatic properties has been proposed as a possible sperm factor candidate. This suggestion was supported by the finding that the injection of mRNA encoding PLC $\zeta$ into mouse eggs induced $\mathrm{Ca}^{2+}$ signals indistinguishable from those at fertilization, and that the removal of PLC $\zeta$ from sperm extracts abolished $\mathrm{Ca}^{2+}$ release in eggs (Saunders et al., 2002). A similar response was obtained by microinjecting purified PLC $\zeta$ protein

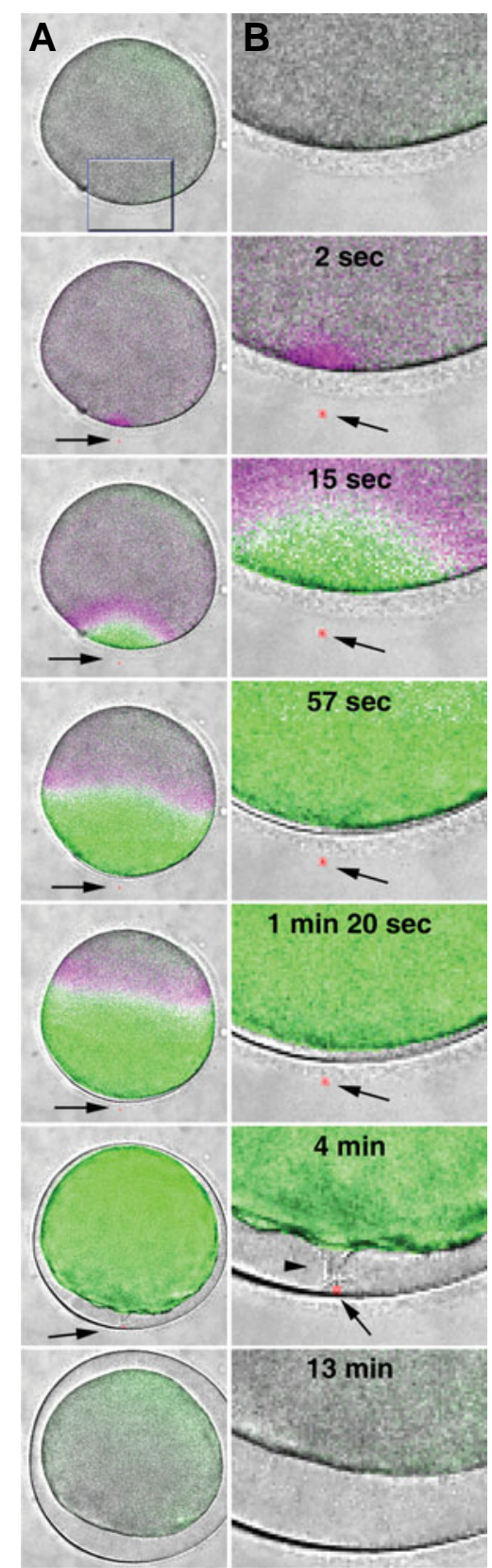

Fig. 5. Elevation of $\mathrm{Ca}^{2+}$ at the time of sperm-egg interaction. After the cortical flash quickly subsides (not shown), a small elevation of $\mathrm{Ca}^{2+}$ starts at the point of sperm interaction, and the $\mathrm{Ca}^{2+}$ wave gradually propagates through the cytoplasm. The process was represented in the merged views of the transmission micrograph and the two relative pseudocolored images depicting either diffusing $\mathrm{Ca}^{2+}$ (in green) or its momentary increment (in pink). The actual release of $\mathrm{Ca}^{2+}$ (pink) obviously precedes its diffusion (green). (A) The whole-cell view of the fertilization process. The cortical region where the sperm meets the egg is indicated with the rectangular box and magnified in the adjacent panels. (B) The magnified views of the same images. It is noticeable that the sperm (the red spot marked with an arrow) induces $\mathrm{Ca}^{2+}$ release before being physically incorporated into the egg. When the fertilization envelope is being elevated, the sperm is apart from the egg surface but connected by the actin-rich acrosomal process and the fertilization cone (arrow head). The sperm enters the egg only when the fertilization envelope is fully elevated. 
that was readily activated by the resting level of the cytoplasmic $\mathrm{Ca}^{2+}$ (Kouchi et al., 2004). In line with these results, reduction of sperm PLC $\zeta$ by transgenic RNAi approach significantly perturbed the number of $\mathrm{Ca}^{2+}$ oscillations, suggesting that the spermderived PLC $\zeta$ may be solely responsible for the signature $\mathrm{Ca}^{2+}$ spiking pattern (Knott et al., 2005). However, what still remains to be understood about PLC $\zeta$ is the exact mode of its action. Indeed, it is not clear how this isoform interacts with plasma membranes since PLC $\zeta$ lacks the PH domain that anchors PLC $\delta 1$ to $\mathrm{PIP}_{2}$. Very recently, it has been demonstrated that a cluster of basic amino acid residues in the X-Y linker region of mouse PLC $\zeta$, which is not present in PLC $\delta 1$, can laterally sequester $\mathrm{PIP}_{2}$ and concentrate it in the region of the catalytic domain (Nomikos et al., 2007). In mouse, however, the expected loss of $\mathrm{PIP}_{2}$ for producing Ins $\mathrm{P}_{3}$ was not detected by a fluorescent probe (PH-GFP) that binds specifically to $\mathrm{PIP}_{2}$ in the plasma membrane. Taken together with the observation that the presence of $\mathrm{PIP}_{2}$ is not evident in the cytoplasmic membranes, these results raise further questions on the location of the polyvalent phoshoinositides to which PLC $\zeta$ may bind for the enzymatic reaction (Halet et al., 2002). Very recently, analysis of the $\mathrm{Ca}^{2+}$ oscillatory pattern in eggs overexpressing PLC $\beta 1$ have shown a decrease in the amount of total $\mathrm{Ca}^{2+}$ liberated inside fertilized eggs, implying that egg PLC $\beta 1$ may be somehow involved in the modulation of the sperm-derived PLC $\zeta$ (Igarashi et al., 2007). Hence, the exact roles of the different isoforms in the PLC family need to be further elucidated in the future study.

\section{$\mathrm{Ca}^{2+}$-linked second messengers other than $\operatorname{InsP}_{3}$ may play a role at fertilization}

The results described above have dealt with the role of InsP in the generation of sperm-induced $\mathrm{Ca}^{2+}$ release. On the other hand, different second messengers may play a subtly different role during the same process, as exemplified by cADPr that contributes to the propagation of the $\mathrm{Ca}^{2+}$ wave. To facilitate the process, the sensitivity of its receptor, ryanodine-sensitive calcium-release channels, is enhanced by $\mathrm{Ca}^{2+}$ through a CICR phenomenon (Galione et al., 1993). The report suggesting cADPr as a primary egg activator raised a question about any specialized roles played by different $\mathrm{Ca}^{2+}$-releasing second messengers. Of particular interest was to discover which second messenger plays a primary role in triggering the first $\mathrm{Ca}^{2+}$ response at fertilization. A clue was provided by the activation pathway of nitric oxide (NO), a signaling molecule acting through the elevation of cellular cGMP. The cGMP-dependence of the sea urchin ADP-ribosyl cyclase has prompted the proposal that NO may be the activating stimulus of the cADPr-signaling pathway (Galione et al., 1993a). The presence of $\mathrm{NO}$ in the sperm during acrosome reaction and in the fertilized eggs could be accountable for the activation of ADP-ribosyl cyclase by cGMP-dependent protein kinase (PKG) and the consequent production of CADPr (Kuo et al., 2000). Indeed, direct measurements of cGMP, cADPr and InsP ${ }_{3}$ contents of sea urchin eggs and the comparison of their levels with the $\mathrm{Ca}^{2+}$ rise during the early stage of sperm activation indicated that cGMP began to rise first and then cADPr followed. By contrast, the major rise in $\mathrm{Ins}_{3}$ occurred after the $\mathrm{Ca}^{2+}$ signal (Kuroda et al., 2001), weakening its role as an inducer of $\mathrm{Ca}^{2+}$ signals. Recently, using a fluorescence indicators of $\mathrm{NO}$ and $\mathrm{Ca}^{2+}$ dyes, both $\mathrm{NO}$ and
$\mathrm{Ca}^{2+}$ increase have been measured simultaneously at fertilization. The results have showed that $\mathrm{NO}$ levels rise after the $\mathrm{Ca}^{2+}$ wave is initiated (Leckie et al., 2003). Again, this observation implies that $\mathrm{NO}$ and CADPr pathway may not be the very first initiating factor of $\mathrm{Ca}^{2+}$ release. Although $\mathrm{NO}$ pathway is still needed to regulate the duration of the $\mathrm{Ca}^{2+}$ wave (Leckie et al., 2003), others have shown that the synthesis of cADPr during sea urchin fertilization is not necessary because inhibitors of either PKG or ADP-ribosyl cyclase activities did not prevent the transient rise in intracellular $\mathrm{Ca}^{2+}$ in heparin-loaded eggs during fertilization (Lee et al., 1996).

The involvement of cADPr/RyRs in the sperm-triggered $\mathrm{Ca}^{2+}$ response is also uncertain in starfish. While the $\mathrm{Ca}^{2+}$ response induced by the uncaged cADPr in mature oocytes was completely blocked by the specific antagonist of the cADPr/ryanodine receptors $\left(8 \mathrm{NH}_{2} \mathrm{CADPr}\right)$, the same antagonist failed to block the sperminduced $\mathrm{Ca}^{2+}$ increase at fertilization (Nusco et al., 2002). Taken together, these observations cast doubt on the role of cADPr as the first initiator of $\mathrm{Ca}^{2+}$ release at the fertilization of echinoderm eggs.

$A$ recently discovered $\mathrm{Ca}^{2+}$-releasing second messenger, NAADP, seems to act on distinct targets that are pharmacologically and physically different from the $\mathrm{Ca}^{2+}$ stores activated by Ins $\mathrm{P}_{3}$ and cADPr. NAAPD is a universal $\mathrm{Ca}^{2+}$-releasing second messenger that mobilizes $\mathrm{Ca}^{2+}$ from intact oocytes and eggs of starfish, ascidians and sea urchin (Lee, 2002). Observations on starfish oocytes matured for 50 min with 1-MA have shown that the $\mathrm{Ca}^{2+}$ response to NAADP consists of a cortical flash that is inhibited in $\mathrm{Ca}^{2+}$-free seawater. The $\mathrm{Ca}^{2+}$ signal then spread centripetally to the center of the oocyte as a wave (Santella et al., 2000; Lim et al., 2001). Since the $\mathrm{Ca}^{2+}$ signal generated by NAADP closely resembles that induced by the sperm, NAADP and $\mathrm{nns}_{3}$ receptors in starfish oocytes have been explored in detail as determinants of the spatiotemporal pattern of $\mathrm{Ca}^{2+}$ signals at fertilization. The striking difference between $\operatorname{InsP}_{3}$ and NAADP was observed in the enucleated oocytes in the presence of 1-MA. Whereas NAADP was potent enough to support cortical granule exocytosis following $\mathrm{Ca}^{2+}$ release in enucleated oocytes, massive $\mathrm{InsP}_{3}$-induced $\mathrm{Ca}^{2+}$ response failed to produce vitelline envelope elevation. On the other hand, the sperm can still fertilize the enucleated oocytes and produce a normal cortical exocytosis even with a slowed $\mathrm{Ca}^{2+}$ wave. Hence, $\mathrm{Ca}^{2+}$ release is not sufficient for the vitelline envelope elevation. In line with this, massive $\mathrm{Ins}_{3}$-induced $\mathrm{Ca}^{2+}$ release in the matured oocytes failed to produce cortical granule exocytosis in the presence of the agents perturbing the organization of cortical actin cytoskeleton (Kyozuka et al., 2008). Based on these observations, it was postulated that NAADP is more responsible for the initiation of $\mathrm{Ca}^{2+}$ waves at the cortex, while $\mathrm{Ins}_{3}$-sensitive $\mathrm{Ca}^{2+}$ stores may mediate the propagation of the waves initiated by NAADP (Lim et al., 2001). The NAADP-induced $\mathrm{Ca}^{2+}$ response is closely preceded by the activation of a membrane current which is responsible for the $\mathrm{Ca}^{2+}$ entry from the extracellular space and for the triggering of the global $\mathrm{Ca}^{2+}$ wave in the egg (Moccia et al., 2003). Interestingly, modification of cortical actin layers by LAT-A or jasplakinolide led to severe reduction of the NAADP-mediated membrane current. Hence, the main action of NAADP takes place at the cell surface, and the idea that NAADP may initiate the intracellular $\mathrm{Ca}^{2+}$ wave at fertilization has been further reinforced 
by the similarities between the biophysical and pharmacological properties of the sperm-elicited depolarization of membrane potentials and the NAADP-activated $\mathrm{Ca}^{2+}$ current (Moccia et al., 2004). The tentative conclusion is that the NAADP-dependent $\mathrm{Ca}^{2+}$ entry may contribute to the stimulation of $\mathrm{InsP}_{3}$-producing PLC $\gamma$ in starfish oocytes (Runft et al., 2004), which requires micromolar concentration of priming $\mathrm{Ca}^{2+}$ (Rhee, 2001). Alternatively, the NAADP-induced $\mathrm{Ca}^{2+}$ may help sensitize the InsP ${ }_{3} \mathrm{Rs}$ through a process of CICR (Moccia et al., 2006). At any rate, these results suggest that $\mathrm{Ca}^{2+}$ signaling during starfish fertilization is initiated by NAADP, although it has been assumed to be exclusively under the control of the $\operatorname{Ins}_{3}$.

In intact sea urchin eggs, NAADP evoked long-lasting $\mathrm{Ca}^{2+}$ oscillations in the absence of extracellular $\mathrm{Ca}^{2+}$, suggesting that the mobilized $\mathrm{Ca}^{2+}$ may be from the intracellular stores (Churchill and Galione, 2001). More recent findings, however, have indicated that the response involves, as in starfish oocytes, a cortical flash produced by $\mathrm{Ca}^{2+}$ influx. It was reported that such $\mathrm{Ca}^{2+}$ burst was inhibited by the desensitization of NAADP receptors by preinjection of sub-threshold concentrations of NAADP, which presumably inactivates the channel (Lee, 2002). The finding that NAADP desensitization also prevented the onset of the fertilization potential in starfish eggs corroborated the involvement of NAADP in the fertilization process (Moccia et al., 2006a). In line with this idea, it has been reported that sea urchin sperm contains large amounts of NAADP, which could be delivered directly into the eggs (Billington et al., 2002; Churchill et al., 2003). What remains to be clarified is the nature of the $\mathrm{Ca}^{2+}$ store activated by NAADP. In sea urchin eggs, it has been suggested that the spermactivated NAADP-sensitive $\mathrm{Ca}^{2+}$ store is located on lysosomelike organelles. However, in other cell types, agents that disrupt lysosomes failed to block or reduce the NAADP-induced $\mathrm{Ca}^{2+}$ response, which could be mediated through ryanodine receptors (Gerasimenko and Gerasimenko, 2004; Steen et al., 2007). In starfish oocytes, neither drugs which disrupt acidic compartments nor inhibitors of RyRs affected the NAADP-induced depolarization and the cortical $\mathrm{Ca}^{2+}$ influx (Moccia et al., 2006a). Hence, as neither the identity of the functional receptors, nor the exact location of its action is known for NAADP, the molecular detail of the $\mathrm{Ca}^{2+}$-releasing action by NAADP is still an open question.

\section{Conclusion}

Aside from its pivotal role in muscle contraction, $\mathrm{Ca}^{2+}$ has been known to be essential to egg activation since nearly 90 years ago. Complementing the electrophysiological tools, the technical advancement of luminescent $\mathrm{Ca}^{2+}$ sensors and ionophores has visually demonstrated that fertilization starts with massive mobilization of intracellular $\mathrm{Ca}^{2+}$, and that the instantaneous $\mathrm{Ca}^{2+}$ signaling is crucial for the formation of fertilization membrane and the catalysis of other processes related to egg activation. The multidisciplinary studies in the past two decades have revealed some of the key mechanisms in which $\mathrm{Ca}^{2+}$ is released from the intracellular stores. The spotlight has been focused on the three major second messengers that release $\mathrm{Ca}^{2+}$ inside the cell, namely InsP ${ }_{3}$, cADPr and NAADP. Among the three, InsP $\mathrm{P}_{3}$ is the best characterized one, and it may play a central role in generating $\mathrm{Ca}^{2+}$ waves in many cell types. Indeed, an isoform of the InsP ${ }_{3}^{-}$ producing enzyme designated PLC- $\zeta$ has been recently recog- nized as a strong candidate for a long-sought "sperm factor" that transduces sperm-borne signals in the fertilized eggs. Intensive studies on the corresponding receptors of these second messengers, e.g. InsP $\mathrm{P}_{3} \mathrm{R}$ and $\mathrm{RyR}$, have elucidated how $\mathrm{Ca}^{2+}$ can diffuse and propagate as a wave with the concept of CICR. Hence, these three and possibly other second messengers may play distinct but concerted roles in shaping the characteristic $\mathrm{Ca}^{2+}$ response in the egg. However, many questions are yet to be answered on this subject. First of all, the identity of the NAADP receptor is not fully established, and another fundamental question is whether or not the $\mathrm{Ca}^{2+}$-releasing actions of these second messengers are mediated exclusively by those corresponding receptors. Whichever may be the answer, it is now becoming evident that the efficacy of the ligand-gated ion channels is significantly influenced by the surrounding cytoskeletal microenvironment. Actin filaments in the oocyte cortex undergo rapid re-organization and turnover during maturation and fertilization. Recent studies have indicated that actin filaments may play direct or indirect roles in intracellular $\mathrm{Ca}^{2+}$ mobilization and exocytosis, as well as in chromosome sorting. There is no doubt that actin cytoskeleton has structural roles, but it requires further studies to understand whether and how these dynamically re-organizing actin filaments play highly regulated functional roles in egg activation.

\section{Acknowledgements}

We thank Mr. G. Gragnaniello and Dr. E. Garante for the assistance in the preparation of the figures. This work was partially supported by the financial support from the Regione Campania, Italy.

\section{References}

ADEBANJO, O.A., ANANDATHEERTHAVARADA, H.K., KOVAL, A.P., MOONGA, B.S., BISWAS, G., SUN, L., SODAM, B.R., BEVIS, P., HUANG, C., EPSTEIN, S. et al. (1999). A new function for CD38/ADP-ribosyl cyclase in nuclear $\mathrm{Ca}^{2+}$ homeostasis. Nat. Cell Biol. 1: 409-14.

BAILLY, E., DORÉE, M., NURSE, P. and BORNENS, M. (1989). p34cdc2 is located in both nucleus and cytoplasm; part is centrosomally associated at G2/M and enters vesicles at anaphase. EMBO J. 8: 3985-95.

BECKHELLING, C., MONGIOVI, D.P. and HOULISTON, E. (2000). Localised MPF regulation in eggs. Biol. Cell. 92: 245-53.

BILLINGTON, R.A., HO, A. and GENAZZANI, A.A. (2002). Nicotinic acid adenine dinucleotide phosphate (NAADP) is present at micromolar concentrations in sea urchin spermatozoa. J. Physiol. 544: 107-12.

BOOTMAN, M.D., THOMAS, D., TOVEY, S.C., BERRIDGE, M.J. and LIPP, P (2000). Nuclear calcium signaling. Cell. Mol. Life Sci. 57: 371-8.

BRINI, M., MURGIA, M., PASTI, L., PICARD, D., POZZAN, T. and RIZZUTO, R. (1993). Nuclear $\mathrm{Ca}^{2+}$ concentration measured with specifically targeted recombinant aequorin. EMBO J. 12: 4813-9.

CARAFOLI, E., SANTELLA, L., BRANCA, D. and BRINI, M. (2001). Generation, control, and processing of cellular calcium signals. Critic. Rev. Biochem. Mol. Biol. 153: 107-260.

CARRIÓN, A.M., LINK, W.A., LEDO, F., MELLSTRÖM, B. and NARANJO, J.R. (1999). DREAM is a $\mathrm{Ca}^{2+}$-regulated transcriptional repressor. Nature. 398: 804.

CARROLL, D.J., RAMARAO, C.S., MEHLMANN, L.M., ROCHE, S., TERASAKI, M. and JAFFE, L.A. (1997). Calcium release at fertilization in starfish eggs is mediated by phospholipase Cgamma. J. Cell Biol. 138: 1303-11.

CHIBA, K., KADO, R.T. and JAFFE, L.A. (1990). Development of calcium release mechanisms during starfish oocyte maturation. Dev. Biol. 140: 300-6.

CHIBA, K., LONGO, F.J., KONTANI, K., KATADA, T. and HOSHI, M. (1995). A periodic network of $G$ protein beta gamma subunit coexisting with cytokeratin filament in starfish oocytes. Dev. Biol. 169: 415-20. 
CHUN, J.T. and SANTELLA, L. (2007). Calcium and fertilization. in Calcium: a matter of life and death. Elsevier BV vol 41: 425-444.

CHURCHILL, G. and GALIONE, A. (2001). NAADP induces $\mathrm{Ca}^{2+}$ oscillations via a two-pool mechanism by priming $\mathrm{IP}_{3}$ - and $\mathrm{CADPR}$-sensitive $\mathrm{Ca}^{2+}$ stores. $E M B O$ J. 20: 2666-71.

CHURCHILL, G.C., O'NEILL, J.S., MASGRAU, R., PATEL, S., THOMAS, J.M., GENAZZANI, A.A. and GALIONE, A. (2003). Sperm deliver a new second messenger: NAADP. Curr. Biol. 13: 125-8.

CLAPPER, D., WALSETH, T., DARGIE, P. and LEE, H.C. (1987). Pyridine nucleotide metabolites stimulate calcium release from sea urchin egg microsomes desensitized to inositol trisphosphate. J. Biol.Chem. 262: 9561-8.

COCCO, L., MARTELLI, A. and GILMOUR, R.S. (1994). Inositol lipid cycle in the nucleus. Cell Signal. 6: 481-5.

DALE, B., DAN-SOHKAWA, M., DE SANTIS, A. and HOSHI, M. (1981). Fertilization of the starfish Astropecten aurantiacus. Exp. Cell Res. 132: 505-10.

DALE, B., DE FELICE, L. and EHRENSTEIN, G. (1985). Injection of a soluble sperm fraction into sea-urchin eggs triggers the cortical reaction. Experientia 41: 106870.

DAN, J. (1960). Studies on the acrosome. VI. Fine structure of the starfish acrosome. Exp. Cell Res. 19: 13-28.

DE NADAI, C., CAILLIAU, K., EPEL, D. and CIAPA, B. (1998). Detection of phospholipase $C$ gamma in sea urchin eggs. Dev. Growth Differ. 40: 669-76.

DENG, M.-Q. and SHEN, S.S. (2000). A Specific Inhibitor of p34cdc2/Cyclin B Suppresses Fertilization-Induced Calcium Oscillations in Mouse Eggs. Biol. Reprod. 62: 873-8.

DIVECHA, N., BANFIC, H. and IRVINE, R.F. (1991). The polyphosphoinositide cycle exists in the nuclei of Swiss 3T3 cells under the control of a receptor (for IGF-I) in the plasma membrane, and stimulation of the cycle increases nuclear diacylglycerol and apparently induces translocation of protein kinase $C$ to the nucleus. EMBO J. 10: 3207-14.

DORÉE, M. and HUNT, T. (2002). From Cdc2 to Cdk1: when did the cell cycle kinase join its cyclin partner? J. Cel/ Sci. 115: 2461-4.

DORÉE, M., MOREAU, M. and GUERRIER, P. (1978). Hormonal control of meiosis. In vitro induced release of calcium ions from the plasma membrane in starfish oocytes. Exp. Cell Res. 115: 251-60.

ECHEVARRÍA, W., LEITE, M.F., GUERRA, M.T., ZIPFEL, W.R. and NATHANSON, M.H. (2003). Regulation of calcium signals in the nucleus by a nucleoplasmic reticulum. Nat. Cell Biol. 5: 440-6.

EISEN, A. and REYNOLDS, G.T. (1984). Calcium transients during early development in single starfish (Asterias forbesi) oocytes. J. Cell Biol. 99: 1878-82.

EPEL, D. (1990). The initiation of development at fertilization. Cel/ Differ. Dev. 29: 1-12.

FISSORE, R.A., LONGO, F.J., ANDERSON, E., PARYS, J.B. and DUCIBELLA, T. (1999). Differential Distribution of Inositol Trisphosphate Receptor Isoforms in Mouse Oocytes. Biol. Reprod. 60: 49-57.

FUJIWARA, T., NAKADA, K., SHIRAKAWA, H. and MIYAZAKI, S. (1993). Development of inositol trisphosphate-induced calcium release mechanism during maturation of hamster oocytes. Dev. Biol. 156: 69-79.

GALIONE, A., MCDOUGALL, A., BUSA, W.B, WILLMOTT, N., GILLOT, I. and WHITAKER, M. (1993) Redundant mechanisms of calcium-induced calcium release underlying calcium waves during fertilization of sea urchin eggs. Science. 261:348-52.

GALIONE, A., WHITE, A., WILLMOTT, N., TURNER, M., POTTER, B.V. and WATSON, S.P. (1993a). cGMP mobilizes intracellular $\mathrm{Ca}^{2+}$ in sea urchin eggs by stimulating cyclic ADP-ribose synthesis. Nature. 365: 456-9.

GENAZZANI, A.A. and GALIONE, A. (1996). Nicotinic acid-adenine dinucleotide phosphate mobilizes $\mathrm{Ca}^{2+}$ from a thapsigargin-insensitive pool. Biochem. J. 315: 721-5.

GERASIMENKO, O. and GERASIMENKO, J. (2004). New aspects of nuclear calcium signaling. J. Cell Sci. 117: 3087-94.

GERASIMENKO, O.V., GERASIMENKO, J.V., TEPIKIN, A.V. and PETERSEN, O.H. (1995). ATP-dependent accumulation and inositol trisphosphate- or cyclic ADP-ribose-mediated release of $\mathrm{Ca}^{2+}$ from the nuclear envelope. Cell. 80: 43944.

GUERRIER, P., MOREAU, M. and DORĖE, M. (1977). Hormonal control of meiosis in starfish: stimulation of protein phosphorylation induced by 1-methyladenine. Mol. Cell Endocrinol. 7: 137-50.

GUERRIER, P., MOREAU, M., MEIJER, L., MAZZEI, G., VILAIN, J.P. and DUBÉ, F. (1982). The role of calcium in meiosis reinitiation. Prog.Clin.Biol. Res. 82: 139-55.

HALET, G., TUNWELL, R., BALLA, T., SWANN, K. and CARROLL, J. (2002). The dynamics of plasma membrane Ptdlns $(4,5) \mathrm{P}(2)$ at fertilization of mouse eggs. J. Cell Sci. 115: 2139-49.

HARDINGHAM, G.E., ARNOLD, F.J. and BADING, H. (2001). Nuclear calcium signaling controls CREB-mediated gene expression triggered by synaptic activity. Nat. Neurosci. 4: 261-7.

HE, C.L., DAMIANI, P., PARYS, J.B. and FISSORE, R.A. (1997). Calcium, calcium release receptors, and meiotic resumption in bovine oocytes. Biol. Reprod. 57: 1245-55.

HIROHASHI, N., VILELA-SILVA, A.C., MOURÃO, P.A. and VACQUIER, V.D. (2002). Structural requirements for species-specific induction of the sperm acrosome reaction by sea urchin egg sulfated fucan. Biochem. Biophys. Res. Commun. 298: 403-7.

IGARASHI, H., KNOTT, J.G., SCHULTZ, R.M. and WILLIAMS, C.J. (2007). Alterations of PLCbeta1 in mouse eggs change calcium oscillatory behavior following fertilization. Dev. Biol. 312: 321-330.

IWASAKI, H., CHIBA, K., UCHIYAMA, T., YOSHIKAWA, F., SUZUKI, F., IKEDA M., FURUICHI, T. and MIKOSHIBA, K. (2002). Molecular characterization of the starfish inositol 1,4,5-trisphosphate receptor and its role during oocyte maturation and fertilization. J. Biol. Chem. 277: 2763-72.

JAFFE, L.A. and TERASAKI, M. (1994). Structural Changes of the Endoplasmic Reticulum of Sea Urchin Eggs during Fertilization. Dev. Biol. 164: 579-87.

JAFFE, L.A., TURNER, P.R., KLINE, D., KADO, R.T. and SHILLING, F. (1988). Gproteins and egg activation. Cell Differ. Dev. 25 suppl: 15-8.

KANATANI, H. and HIRAMOTO, Y. (1970). Site of action of 1-methyladenine in inducing oocyte maturation in starfish. Exp. Cell Res. 61: 280-4.

KANATANI, H., SHIRAI, K., NAKANISHI, K. and KUROKAWA, T. (1969). Isolation and identification on meiosis inducing substance in starfish Asterias amurensis. Nature. 18: 273-4.

KISHIMOTO, T. (1999). Activation of MPF at meiosis reinitiation in starfish oocytes Dev. Biol. 214: 1-8.

KNOTT, J.C., KUROKAWA, M., FISSORE, R.A., SCHULTZ, R.M. and WILLIAMS, C.J. (2005). Transgenic RNA interference reveals role for mouse sperm phospholipase $\mathrm{C}$ zeta in triggering $\mathrm{Ca}^{2+}$ oscillations during fertilization. Biol. Reprod. 72: 992-6.

KOUCHI, Z., FUKAMI, K., SHIKANO, T., ODA, S., NAKAMURA, Y., TAKENAWA, T. and MIYAZAKI, S. (2004). Recombinant phospholipase $C$ zeta has high $\mathrm{Ca}^{2+}$ sensitivity and induces $\mathrm{Ca}^{2+}$ oscillations in mouse eggs. J. Biol. Chem. 279: 10408-12.

KUO, R.C., BAXTER, G.T., THOMPSON, S.H., STRICKER, S.A., PATTON, C., BONAVENTURA, J. and EPEL, D. (2000). NO is necessary and sufficient for egg activation at fertilization. Nature. 406: 633-6.

KURODA, R., KONTANI, K., KANDA, Y., KATADA, T., NAKANO, T., SATOH, Y., SUZUKI, N. and KURODA, H. (2001). Increase of cGMP, CADP-ribose and inositol 1,4,5-trisphosphate preceding $\mathrm{Ca}\left({ }^{2+}\right)$ transients in fertilization of sea urchin eggs. Development. 128: 4405-14.

KYOZUKA, K., DEGUCHI, R., MOHRI, T. and MIYAZAKI, S. (1998). Injection of sperm extract mimics spatiotemporal dynamics of $\mathrm{Ca}^{2+}$ responses and progression of meiosis at fertilization of ascidian oocytes. Development. 125: 4099-105.

KYOZUKA, K., J. T. CHUN, PUPPO, A., GRAGNANIELLO, G., GARANTE, E. and SANTELLA, L. (2008). Actin cytoskeleton modulates calcium signaling during maturation of starfish oocytes. Dev. Biol. (DOI: 10.1016/J.ydbio.2008.05.549)

LAFLAMME, K., DOMINGUE, O., GUILLEMETTE, B.I. and GUILLEMETTE, G. (2002). Immunohistochemical localization of type 2 inositol 1,4,5-trisphosphate receptor to the nucleus of different mammalian cells. J. Cell Biochem. 85: 21928.

LECKIE, C., EMPSON, R., BECCHETTI, A., THOMAS, J., GALIONE, A. and WHITAKER, M. (2003). The NO pathway acts late during the fertilization response in sea urchin eggs. J. Biol. Chem. 278: 12247-54.

LEE, H.C. (2002). Cyclic ADP-ribose and NAADP. Structures, metabolism and 
functions. Hon Cheung Lee (ed) Kluwer Academic publishers.

LEE, H.C. and AARHUS, R. (1991). ADP-ribosyl cyclase: an enzyme that cyclizes NAD+ into a calcium-mobilizing metabolite. Cell Regul. 2: 203-9.

LEE, S.J., CHRISTENSON, L., MARTIN, T. and SHEN, S.S. (1996). The cyclic GMP-mediated calcium release pathway in sea urchin eggs is not required for the rise in calcium during fertilization. Dev. Biol. 180: 324-35.

LÉNÁRT, P., BACHER, C.P., DAIGLE, N., HAND, A.R., EILS, R., TERASAKI, M. and ELLENBERG, J. (2005). A contractile nuclear actin network drives chromosome congression in oocytes. Nature. 436: 812-18.

LEVASSEUR, M. and MCDOUGALL, A. (2000). Sperm-induced calcium oscillations at fertilisation in ascidians are controlled by cyclin B1-dependent kinase activity. Development. 127: 746-50.

LIM, D., ERCOLANO, E., KYOZUKA, K., NUSCO, G.A., MOCCIA, F., LANGE, K. and SANTELLA, L. (2003). The M-phase-promoting factor modulates the sensitivity of the $\mathrm{Ca}^{2+}$ stores to inositol 1,4,5-trisphosphate via the actin cytoskeleton. J. Biol. Chem. 278: 42505-14.

LIM, D., KYOZUKA, K., GRAGNANIELLO, G., CARAFOLI, E. and SANTELLA, L. (2001). NAADP+ initiates the $\mathrm{Ca}^{2+}$ response during fertilization of starfish oocytes. FASEB J. 15: 2257-67.

LIM, D., LANGE, K. and SANTELLA, L. (2002). Activation of oocytes by latrunculin A. FASEB J. 16: 1050-6.

LONGO, F.J., LYNN, J.W., MCCULLOH, D.H. and CHAMBERS, E.L. (1986) Correlative ultrastructural and electrophysiological studies of sperm-egg interactions of the sea urchin, Lytechinus variegatus. Dev Biol. 118:155-66.

LONGO, F.J., WOERNER, M., CHIBA, K. and HOSHI, M. (1995). Cortical changes in starfish (Asterina pectinifera) oocytes during 1-methyladenine-induced maturation and fertilisation/activation. Zygote. 3: 225-39.

LUI, P.P.Y., LEE, C.Y., TSANG, D. and KONG, S.K. (1998). Ca ${ }^{2+}$ is released from the nuclear tubular structure into nucleoplasm in $\mathrm{C} 6$ glioma cells after stimulation with phorbol ester. FEBS Lett. 432: 82-7.

MACAULAY, C., MEIER, E. and FORBES, D.J. (1995). Differential mitotic phosphorylation of proteins of the nuclear pore complex. J. Biol. Chem. 270: 254-62.

MALCUIT, C., KNOTT, J.G., HE, C., WAINWRIGHT, T., PARYS, J.B., ROBL, J.M. and FISSORE, R.A. (2005). Fertilization and Inositol 1,4,5-Trisphosphate (IP3)Induced Calcium Release in Type-1 Inositol 1,4,5-Trisphosphate Receptor Down-Regulated Bovine Eggs. Biol. Reprod. 73: 2-13.

MARANGOS, P. and CARROLL, J. (2004). Fertilization and InsP3-induced $\mathrm{Ca}^{2+}$ release stimulate a persistent increase in the rate of degradation of cyclin B1 specifically in mature mouse oocytes. Dev. Biol. 272: 26-38.

MARIUS, P., GUERRA, M.T., NATHANSON, M.H., EHRLICH, B.E. and LEITE, M.F. (2006). Calcium release from ryanodine receptors in the nucleoplasmic reticulum. J. Cell Biol. 163: 271-82.

MASUI, Y. (2001). From oocyte maturation to the in vitro cell cycle: the history of discoveries of Maturation-Promoting Factor (MPF) and Cytostatic Factor (CSF). Differentiation. 69: 1-17.

MCDOUGALL, A., SHEARER, J. and WHITAKER, M. (2000). The initiation and propagation of the fertilization wave in sea urchin eggs. Biol. Cell. 92: 205-14.

MEHLMANN, L.M., MIKOSHIBA, K. and KLINE, D. (1996). Redistribution and Increase in Cortical Inositol 1,4,5-Trisphosphate Receptors after Meiotic Maturation of the Mouse Oocyte. Dev. Biol. 180: 489-98.

MEHLMANN, L.M., TERASAKI, M., JAFFE, L.A. and KLINE, D. (1995). Reorganization of the Endoplasmic Reticulum during Meiotic Maturation of the Mouse Oocyte. Dev. Biol. 170: 607-15.

MEIJER, L. and GUERRIER, P. (1984). Maturation and fertilization in starfish oocytes. Int. Rev. Cytol. 86: 129-96.

MIYATA, K., NAKANO, T., KURODA, R. and KURODA, H. (2006). Development of calcium releasing activity induced by inositol trisphosphate and cyclic ADPribose during in vitro maturation of sea urchin oocytes. Dev. Growth Differ. 48: 605-13.

MIYAZAKI, S., YUZAKI, M., NAKADA, K., SHIRAKAWA, H., NAKANISHI, S., NAKADE, S. and MIKOSHIBA, K. (1992). Block of $\mathrm{Ca}^{2+}$ wave and $\mathrm{Ca}^{2+}$ oscillation by antibody to the inositol 1,4,5-trisphosphate receptor in fertilized hamster eggs. Science. 257: 251-5.

MOCCIA, F., BILLINGTON, R.A. and SANTELLA, L. (2006a). Pharmacological characterization of NAADP-induced $\mathrm{Ca}^{2+}$ signals in starfish oocytes. Biochem.
Biophys. Res. Commun. 348: 329-36.

MOCCIA, F., LIM, D., KYOZUKA, K. and SANTELLA, L. (2004). NAADP triggers the fertilization potential in starfish oocytes. Cell Calcium. 36: 515-24.

MOCCIA, F., NUSCO GA, LIM D, KYOZUKA K and SANTELLA L. (2006). NAADP and InsP3 play distinct roles at fertilization in starfish oocytes. Dev. Biol. 294:2438.

MOCCIA, F., NUSCO, G.A., LIM, D., ERCOLANO, E., GRAGNANIELLO, G., BROWN, E.R. and SANTELLA, L. (2003). $\mathrm{Ca}^{2+}$ signaling and membrane current activated by cADPr in starfish oocytes. Pflugers Arch. 541-52: 5.

MOREAU, M., GUERRIER, P., DORÈE, M. and ASHLEY, C.C. (1978). Hormoneinduced release of intracellular $\mathrm{Ca}^{2+}$ triggers meiosis in starfish oocytes. Nature. 61: $280-4$

MUELLER, P.R., COLEMAN, T.R., KUMAGAI, A. and DUNPHY, W.G. (1995). Myt1: a membrane-associated inhibitory kinase that phosphorylates Cdc2 on both threonine-14 and tyrosine-15. Science. 270: 86-90.

NAKACHI, M., MORIYAMA, H., HOSHI, M. and MATSUMOTO, M. (2006). Acrosome reaction is subfamily specific in sea star fertilization. Dev. Biol. 298: 597-604.

NOMIKOS, M., MULGREW-NESBITT, A., PALLAVI, P., MIHALYNE, G., ZAITSEVA, I., SWANN, K., LAI, F.A., MURRAY, D. and MCLAUGHLIN, S. (2007). Binding of phosphoinositide-specific phospholipase C-zeta (PLC-zeta) to phospholipid membranes: potential role of an unstructured cluster of basic residues. J. Biol. Chem. 282: 16644-53.

NUSCO, G., LIM D, SABALA P and SANTELLA L. (2002). Ca(2+) response to CADPr during maturation and fertilization of starfish oocytes. Biochem. Biophys. Res. Commun. 290: 1015-21.

Nusco, G.A., CHUN, J.T., ERCOLANO, E., LIM, D., GRAGNANIELLO, G., KYOZUKA, K. and SANTELLA, L. (2006). Modulation of calcium signaling by the actin-binding protein cofilin. Biochem. Biophys. Res. Commun. 348: 109-14.

OKUMURA, E., FUKUHARA, T., YOSHIDA, H., HANADA, S.-I., KOZUTSUMI, R., MORI, M., TACHIBANA, K. and KISHIMOTO, T. (2002). Akt inhibits Myt1 in the signaling pathway that leads to meiotic G2/M-phase transition. Nat. Cel/ Biol. 4: 111-6.

OOKATA, K., HISANAGA S, OKUMURA E and KISHIMOTO T. (1993). Association of p34cdc2/cyclin B complex with microtubules in starfish oocytes. J.Cel/ Sci. 105: 873-81.

OOKATA, K., HISANAGA, S., OKANO, T., TACHIBANA, K. and KISHIMOTO, T. (1992). Relocation and distinct subcellular localization of p34cdc2-cyclin $B$ complex at meiosis reinitiation in starfish oocytes. EMBO J. 11: 1763-72.

OTTO, J.J. and SCHROEDER, T.E. (1984). Assembly-disassembly of actin bundles in starfish oocytes: An analysis of actin-associated proteins in the isolated cortex. Dev. Biol. 101: 263-73.

PARRINGTON, J., BRIND, S., SMEDT, H.D., GANGESWARA, R., LAI, F.A., WOJCIKIEWICZE, R. and CARROLL, J. (1998). Expression of Inositol 1,4,5Trisphosphate Receptors in Mouse Oocytes and Early Embryos: The Type I Isoform Is Upregulated in Oocytes and Downregulated after Fertilization. Dev. Biol. 203: 451-461.

PARRINGTON, J., DAVIS, L.C., GALIONE, A. and WESSEL, G. (2007). Flipping the switch: how a sperm activates the egg at fertilization. Dev. Dyn. 236: 202738.

PATEL, R., HOLT, M., PHILIPOVA, R., MOSS, S., SCHULMAN, H., HIDAKA, H. and WHITAKER, M. (1999). Calcium/Calmodulin-dependent Phosphorylation and Activation of Human Cdc25-C at the G2/M Phase Transition in HeLa Cells. J. Biol. Chem. 274: 7958-68.

PEREZ-TERZIC, C., JACONI, M. and CLAPHAM, D.E. (1997). Nuclear calcium and the regulation of the nuclear pore complex. BioEssays. 19: 787-92.

PICARD, A. and DORÉE, M. (1984). The role of the germinal vesicle in producing maturation-promoting factor (MPF) as revealed by the removal and transplantation of nuclear material in starfish oocytes. Dev. Biol. 104: 357-65.

PICARD, A., GIRAUD, F., BOUFFANT, F.L., SLADECZEK, F., LEPEUCH, C. and DORÉE, M. (1985). Inositol 1,4,5-triphosphate microinjection triggers activation, but not meiotic maturation in amphibian and starfish oocytes. FEBS Lett. 182: $446-450$

POENIE, M., ALDERTON, J., TSIEN, R.Y. and STEINHARDT, R.A. (1985). Changes of free calcium levels with stages of the cell division cycle. Nature. 315 : 147-9. 
PRIGENT, C. and HUNT, T. (2004) Oocyte maturation and cell cycle control: a farewell symposium for Pr Marcel Dorée. Biol. Cell. 96:181-5.

RHEE, S.G. (2001). Regulation of phosphoinositide-specific phospholipase C. Annu. Rev. Biochem. 70: 281-312.

RUNFT, L.L., CARROLL, D.J., GILLETT, J., GIUSTI, A.F., O'NEILL, F.J. and FOLTZ, K.R. (2004). Identification of a starfish egg PLC-gamma that regulates $\mathrm{Ca}^{2+}$ release at fertilization. Dev. Biol. 269: 220-36.

SANTELLA, L. (1996). The Cell Nucleus: An Eldorado to Future Calcium Research? J. Membr. Biol. 153: 83-92.

SANTELLA, L. (1998). The role of calcium in the cell cycle: facts and hypotheses. Biochem. Biophys. Res. Commun. 244: 317-24.

SANTELLA, L. (2005). NAADP: a new second messenger comes of age. Mol. Interv. 5: 70-2.

SANTELLA, L. and CARAFOLI, E. (1997). Calcium signaling in the cell nucleus. FASEB J. 11: 1091-109.

SANTELLA, L., DE RISO, L., GRAGNANIELLO, G. and KYOZUKA, K. (1999). Cortical Granule Translocation during Maturation of Starfish Oocytes Requires

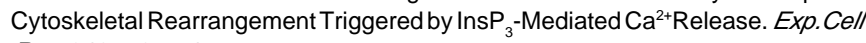
Res. 248: 567-74.

SANTELLA, L., ERCOLANO, E., LIM, D., NUSCO, G.A. and MOCCIA, F. (2003). Activated M-phase-promoting factor (MPF) is exported from the nucleus of starfish oocytes to increase the sensitivity of the $\operatorname{lns}(1,4,5) \mathrm{P}_{3}$ receptors. Biochem. Soc. Trans. 31: 79-82.

SANTELLA, L. and KYOZUKA, K. (1994). Reinitiation of meiosis in starfish oocytes requires an increase in nuclear $\mathrm{Ca}^{2+}$. Biochem. Biophys. Res. Commun. 203: 674-80.

SANTELLA, L. and KYOZUKA, K. (1997). Effects of 1-methyladenine on nuclear $\mathrm{Ca}^{2+}$ transients and meiosis resumption in starfish oocytes are mimicked by the nuclear injection of inositol 1,4,5-trisphosphate and cADP-ribose. Cel/ Calcium. 22: 11-20.

SANTELLA, L. and KYOZUKA, K. (1997a). Association of calmodulin with nuclear structures in starfish oocytes and its role in the resumption of meiosis. Eur. J. Biochem. 246: 602-10.

SANTELLA, L., KYOZUKA, K., GENAZZANI, A.A., DE RISO, L. and CARAFOLI, E. (2000). Nicotinic acid adenine dinucleotide phosphate-induced $\mathrm{Ca}(2+)$ release. Interactions among distinct $\mathrm{Ca}(2+)$ mobilizing mechanisms in starfish oocytes. J. Biol. Chem. 275: 8301-6.

SANTELLA, L., LIM, D. and MOCCIA, F. (2004). Calcium and fertilization: the beginning of life. Trends Biochem. Sci. 29: 400-8.

SAUNDERS, C., LARMAN, M.G., PARRINGTON, J., COX, L.J., ROYSE, J., BLAYNEY, L.M., SWANN, K. and LAI, F.A. (2002). PLC zeta: a sperm-specific trigger of $\mathrm{Ca}(2+)$ oscillations in eggs and embryo development. Development. 129: 3533-44.

SCHROEDER, T.E. and STRICKER, S.A. (1983). Morphological changes during maturation of starfish oocytes: Surface ultrastructure and cortical actin. Dev.
Biol. 98: 373-84.

SHAPIRO, B.M. and EDDY, E.M. (1980). When sperm meets egg: biochemical mechanisms of gamete interaction. Inter. Rev. Cytol. 66: 257-302.

STEEN, M., KIRCHBERGER, T. and GUSE, A.H. (2007). NAADP mobilizes calcium from the endoplasmic reticular $\mathrm{Ca}(2+)$ store in T-lymphocytes. J. Biol. Chem. 282: 18864-71.

STRICKER, S.A. (1997). Intracellular injections of a soluble sperm factor trigger calcium oscillations and meiotic maturation in unfertilized oocytes of a marine worm. Dev. Biol. 186: 185-201.

STRICKER, S.A., SILVA, R. and SMYTHE, T. (1998). Calcium and endoplasmic reticulum dynamics during oocyte maturation and fertilization in the marine worm Cerebratulus lacteus. Dev. Biol. 203: 305-22.

STRICKER, S.A. and SMYTHE, T.L. (2003). Endoplasmic reticulum reorganizations and $\mathrm{Ca}^{2+}$ signaling in maturing and fertilized oocytes of marine protostome worms: the roles of MAPKs and MPF. Development. 130: 2867-79.

SU, Y.Q. and EPPIG, J.J. (2002). Evidence that multifunctional calcium/calmodulindependent protein kinase II (CaM KII) participates in the meiotic maturation of mouse oocytes. Mol. Reprod. Dev. 61: 560-9.

SWANN, K. (1990). A cytosolic sperm factor stimulates repetitive calcium increases and mimics fertilization in hamster eggs. Development. 110: 1295-302.

SWANN, K. and WHITAKER, M. (1986). The part played by inositol trisphosphate and calcium in the propagation of the fertilization wave in sea urchin eggs. J. Cell Biol. 103: 2333-42.

TERASAKI, M., OKUMURA, E.-I., HINKLE, B. and KISHIMOTO, T. (2003). Localization and dynamics of Cdc2-cyclin B during meiotic reinitiation in starfish oocytes. Mol. Biol. Cell. 14: 4685-94.

TOSUJI, H., SEKIA, Y. and KYOZUKA, K. (2007). Two phases of calcium requirement during starfish meiotic maturation. Comp. Biochem. Physiol. AMol. Integr. Physiol. 147: 432-7.

TURNER, P.R., JAFFE, L.A. and PRIMAKOFF, P. (1987). A cholera toxin-sensitive G-protein stimulates exocytosis in sea urchin eggs. Dev. Biol. 120: 577-83.

VACQUIER, V.D. (1975). The isolation of intact cortical granules from sea urchin eggs: calcium lons trigger granule discharge. Dev. Biol. 43: 62-74.

WASSERMAN, W.J. and SMITH, L.D. (1978). The cyclic behavior of a cytoplasmic factor controlling nuclear membrane breakdown. J. Cell Biol. 78: R15-22.

WHITAKER, M. (2006). Calcium at fertilization and in early development. Physiol. Rev. 86: 25-88.

WILDING, M., WRIGHT, E.M., PATEL, R., ELLIS-DAVIES, G. and WHITAKER, M. (1996). Local perinuclear calcium signals associated with mitosis-entry in early sea urchin embryos. J. Cell Biol. 135: 191-9.

WITCHEL, H.J. and STEINHARDT, R.A. (1990). 1-Methyladenine can consistently induce a fura-detectable transient calcium increase which is neither necessary nor sufficient for maturation in oocytes of the starfish Asterina miniata. Dev. Biol. 141: 393-8 


\section{Related, previously published Int. J. Dev. Biol. articles}

See our recent Special Issue Developmental Biology in Poland edited by Tarkowski, Maleszewski and Kloc at: http://www.ijdb.ehu.es/web/contents.php?vol=52\&issue=2-3

See our recent Special Issue Ear Development edited by Fernando Giraldez and Bernd Fritzsch at: http://www.ijdb.ehu.es/web/contents.php?vol=51\&issue=6-7

The dynamics of calcium oscillations that activate mammalian eggs

Karl Swann and Yuansong Yu

Int. J. Dev. Biol. (2008) 52: 585-594

Regionalized calcium signaling in zebrafish fertilization Dipika Sharma and William H. Kinsey

Int. J. Dev. Biol. (2008) 52: 561-570

Defective calcium release during in vitro fertilization of maturing oocytes of $L T / S v$ mice Karolina Archacka, Anna Ajduk, Pawel Pomorski, Katarzyna Szczepanska, Marek Maleszewski and Maria A. Ciemerych Int. J. Dev. Biol. (2008) 52: doi: 10.1387/ijdb.072397ka

Developmental gene network analysis.

Roger Revilla-i-Domingo and Eric H Davidson

Int. J. Dev. Biol. (2003) 47: 695-703

Cytoskeletal actin genes function downstream of HNF-3beta in ascidian notochord development.

W R Jeffery, N Ewing, J Machula, C L Olsen and B J Swalla

Int. J. Dev. Biol. (1998) 42: 1085-1092

Metamorphosis and pattern formation in Hydractinia echinata, a colonial hydroid. $M$ Walther, R Ulrich, M Kroiher and S Berking

Int. J. Dev. Biol. (1996) 40: 313-322

Nucleoskeleton and nucleo-cytoplasmic transport in oocytes and early development of Xenopus laevis.

F Rudt, I Firmbach-Kraft, M Petersen, T Pieler and R Stick

Int. J. Dev. Biol. (1996) 40: 273-278

Egg-jelly signal molecules for triggering the acrosome reaction in starfish spermatozoa.

M Hoshi, T Nishigaki, A Ushiyama, T Okinaga, K Chiba and M Matsumoto Int. J. Dev. Biol. (1994) 38: 167-174

The control of oocyte maturation in the starfish and amphibians by serotonin and its antagonists.

G A Buznikov, L A Nikitina, A Y Galanov, L A Malchenko and O B Trubnikova Int. J. Dev. Biol. (1993) 37: 363-364

Hereditary abnormal activation in Pleurodeles waltl oocytes.

A Collenot and C Aimar

Int. J. Dev. Biol. (1993) 37: 609-613

Meiosis reinitiation as a model system for the study of cell division and cell differentiation.

P Guerrier, P Colas and I Neant

Int. J. Dev. Biol. (1990) 34: 93-109

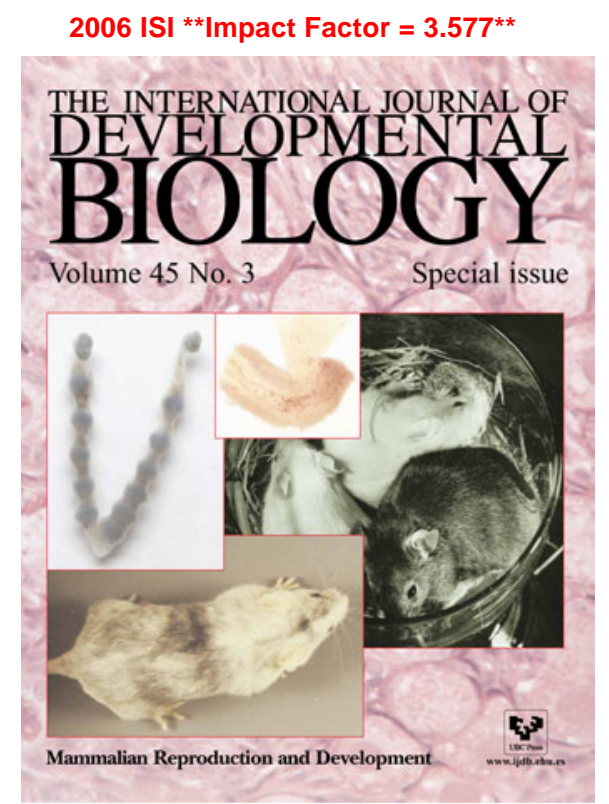

